\title{
Assessing future suitability of tree species under climate change by multiple methods: a case study in southern Germany
}

\author{
H. Walentowski, W. Falk, T. Mette, J. Kunz, A. Bräuning, C. Meinardus, Ch. Zang, \\ L. Sutcliffe, Ch. Leuschner
}

Walentowski H., Falk W., Mette T., Kunz J., Bräuning A., Meinardus C., Zang Ch., Sutcliffe L., Leuschner Ch., 2017. Assessing future suitability of tree species under climate change by multiple methods: a case study in southern Germany. Ann. For. Res. 60(1): 101-126.

Abstract. We compared results derived using three different approaches to assess the suitability of common tree species on the Franconian Plateau in southern Germany under projected warmer and drier climate conditions in the period 2061-2080. The study area is currently a relatively warm and dry region of Germany. We calculated species distribution models (SDMs) using information on species' climate envelopes to predict regional species spectra under 63 different climate change scenarios. We complemented this with fine-scale ecological niche analysis using data from 51 vegetation surveys in seven forest reserves in the study area, and tree-ring analysis (TRA) from local populations of five tree species to quantify their sensitivity to climatic extreme years. The SDMs showed that predicted future climate change in the region remains within the climate envelope of certain species (e.g. Quercus petraea), whilst for e.g. Fagus sylvatica, future climate conditions in one third of the scenarios are too warm and dry. This was confirmed by the TRA: sensitivity to drought periods is lower for $Q$. petraea than for $F$. sylvatica. The niche analysis shows that the local ecological niches of Quercus robur and Fraxinus excelsior are mainly characterized by soils providing favorable water supply than by climate, and Pinus sylvestris (planted) is strongly influenced by light availability. The best adapted species for a warmer and potentially drier climate in the study region are Acer campestre, Sorbus torminalis, S. aria, Ulmus minor, and Tilia platyphyllos, which should therefore play a more prominent role in future climate-resilient mixed forest ecosystems. Keywords broadleaf forests, climate modelling, dendrochronology, drought tolerance, ecological niche, Ellenberg Indicator Values

Authors. Helge Walentowski (helge.walentowski@hawk-hhg.de) - University of Applied Sciences and Arts Hildesheim/Holzminden/Göttingen, Faculty of Resource Management, Büsgenweg 1a, 37077 Göttingen, Germany; Wolfgang Falk - Bavarian Forestry Institute LWF, Department of Soil and Climate, HansCarl-von-Carlowitz-Platz 1, 85354 Freising \& Institute of Geoecology, Dept. of Environmental System Analysis, TU Braunschweig, Langer Kamp 19c, 38106 Braunschweig, Germany; Tobias Mette - Bavarian Forestry Institute LWF, De- 
partment of Soil and Climate, Hans-Carl-von-Carlowitz-Platz 1, 85354 Freising, Germany; Jörg Kunz - Department of Silviculture, Faculty of Environment and Natural Resources, Albert-Ludwig-University Freiburg, Tennenbacherstraße 4, 79106 Albert-Ludwigs-Universität Freiburg, Germany; Achim Bräuning, Cathrin Meinardus - Institute of Geography, Friedrich-Alexander-Universität Erlangen-Nürnberg, Wetterkreuz 15, 91058 Erlangen, Germany; Christian Zang - Land Surface-Atmosphere Interactions, Technical University of Munich, Hans-Carl-von-Carlowitz-Platz 2, 85354 Freising, Germany; Laura M.E. Sutcliffe, Christoph Leuschner - Department of Plant Ecology and Ecosystem Research, Georg-August-University Göttingen, Untere Karspüle 2, 37073 Göttingen, Germany.

Manuscript received January 23, 2017; revised April 17, 2017; accepted April 24, 2017; online first May $2^{\text {nd }}, 2017$.

\section{Introduction}

Climate change is forcing forestry in Central Europe to make forests resilient to future climate conditions. This means temperature rise and, above all, to increasing drought risk (Ciais et al. 2005, Lindner et al. 2010, 2014, IPCC 2013). One of the main silvicultural options is to promote thermophilous and drought-tolerant tree species and to increase the proportion of mixed-species forests in areas that are currently planted with conifers (Brang et al. 2008, Hanewinkel et al. 2013). In Central Europe, the economically important species European beech (Fagus sylvatica L.) and sessile and pedunculate oak (Quercus petraea (Matt.) Liebl. and Quercus robur L.) are expected to play an important role in this transformation process. However, in some regions at least beech may be negatively affected by climate change (Scharnweber et al. 2011, Mette et al. 2013, Zimmermann et al. 2015). Alternative drought tolerant species like wild service tree (Sorbus torminalis (L.) Crantz), field maple (Acer campestre L.), or linden species (Tilia cordata Mill. and Tilia platyphyllos Scop.) are rare and thus far more difficult to assess with respect to their suitability for future forests.

Forest science and forest administrations have produced practical guidelines and maps on drought tolerance and species traits to facilitate management decisions (e.g. Kölling 2007, Hanewinkel et al. 2014). Often, this informa102 tion is presented in form of suitability or risk maps generated on the basis of species distribution models (SDMs; Franklin 2010). SDMs use data from a large geographic area to cover the distribution range and climatic limits of the focal species as precisely as possible. This approach has sometimes been criticized for neglecting more complex interacting factors such as edaphic or topographic characteristics, genetic differences, and anthropogenic interference (Mátyás et al. 2009, Zimmermann et al. 2010, Austin \& Van Niel 2011, Bertrand et al. 2012, Chakraborty et al. 2015). On the other hand, recent progress in statistical modelling now allows a species-specific determination of key environmental factors (Elith et al. 2008, Falk \& Mellert 2011) and the analysis of major climatic constraints on large scales (Pearson \& Dawson 2003). While SDMs are currently the most important tool to assist species selection in forest management, they are still the subject of ongoing research and improvement (Mellert et al. 2015).

One example in which an SDM has been employed as an Ecological Site Classification Decision Support System (ESC-DSS) are the European SDMs developed by the Bavarian State Institute of Forestry (Falk \& Hempelmann 2013, Schueler et al. 2014). These models are based on information on the Europe-wide distribution of over 20 tree species and use semi-parametric regression techniques to describe the relationship between climate 
and species distribution. This approach has been adopted in forest management in the digital site classification system of the Bavarian forest service in Germany (Taeger \& Kölling 2016), where it assists the choice of appropriate tree species under present and future climates for optimum ecological and economic outcomes.

To develop local forest conversion concepts, it is important to start from the assumed present natural forest composition and consider the local niche occupation ("think globally, act locally"). In this regard, natural forest reserves are suitable research objects as they display the (largely) natural competitiveness of tree species resulting from interactions in plant communities/phytocenoses under the current climate. If phytosociological surveys are available, gradient analysis (Hill \& Gauch 1980) and indicator species analysis (Dufrêne \& Legendre 1997, De Cácares et al. 2010) can uncover niche divergence facilitated by finescale ecological partitioning of the tree species. While species' presences like in SDMs or species' abundances in phytocoenoses reflect average site conditions, tree ring analyses on local populations are useful instruments to provide insights into the species' growth response to climatic extreme years (Fritts 1976). Of special interest are recent drought years (e.g. Zang et al. 2011, 2014, Weber et al. 2013, Mette et al. 2015), which are expected to further increase in frequency and severity over the course of the $21^{\text {st }}$ century (Trenberth 2010 , Comou \& Rahmstorf 2012, Seneviratne et al. 2012, Bahn et al. 2015). These analyses of climate-growth relationships based on tree rings allows a long-term evaluation of tree growth under various climatic conditions (Fritts 1976, Cook 1987, Cook \& Peters 1997) and hence a relative ranking of species according to drought tolerance (Friedrichs et al. 2009, Zang et al., 2011, Michelot et al. 2012, Cavin et al. 2013, Pretzsch et al. 2013). As there are only few dendroecological studies addressing less common tree species (Gillner et al. 2014, Zim- mermann et al. 2015, Cedro \& Cedro 2015, Klemmt et al. 2015, Cedro, 2016), a multiple methods approach seems to be promising to assess the future suitability for those species (Piedallu et al. 2013, Fensham et al. 2014).

In this study, we compare the three mentioned approaches: species distribution models, ecological niche analyses, and tree ring analyses on selected regional tree species, with the aims: (1) to find out how selected tree species can be rated with respect to their future suitability under climate change, and (2) to understand similarities and apparent inconsistencies between the different ratings. To our knowledge, this is the first attempt that compares these three common methodological approaches to evaluate tree species' sensitivity to climate change, and one of only a few studies to cross-check species modelling results with other data sources (e.g. Mette et al. 2013). We expect the multiple perspectives from such different methods to provide a more differentiated picture on the ecological determinants of species responses to climate change.

\section{Material and methods}

\section{Study area}

Our study region is located on the Franconian Plateau, northern Bavaria, Germany (see figure 1 ), an area that is largely representative for the growth conditions of the colline-submontane zone of western Central Europe. According to the $3^{\text {rd }}$ German national forest inventory from 2012 (NFI; Polley et al. 2010) the most abundant tree species is Quercus petraea which is found in almost $50 \%$ of the NFI plots of the study area (average for all NFI plots over Germany $10.4 \%$ ). Besides, other warmth-loving broadleaf tree species like Carpinus betulus L., Tilia spp., Acer campestre, and Prunus avium L., are characteristic for the Franconian Plateau (figure 2), an area that experiences relatively warm and dry climate conditions (fig- 


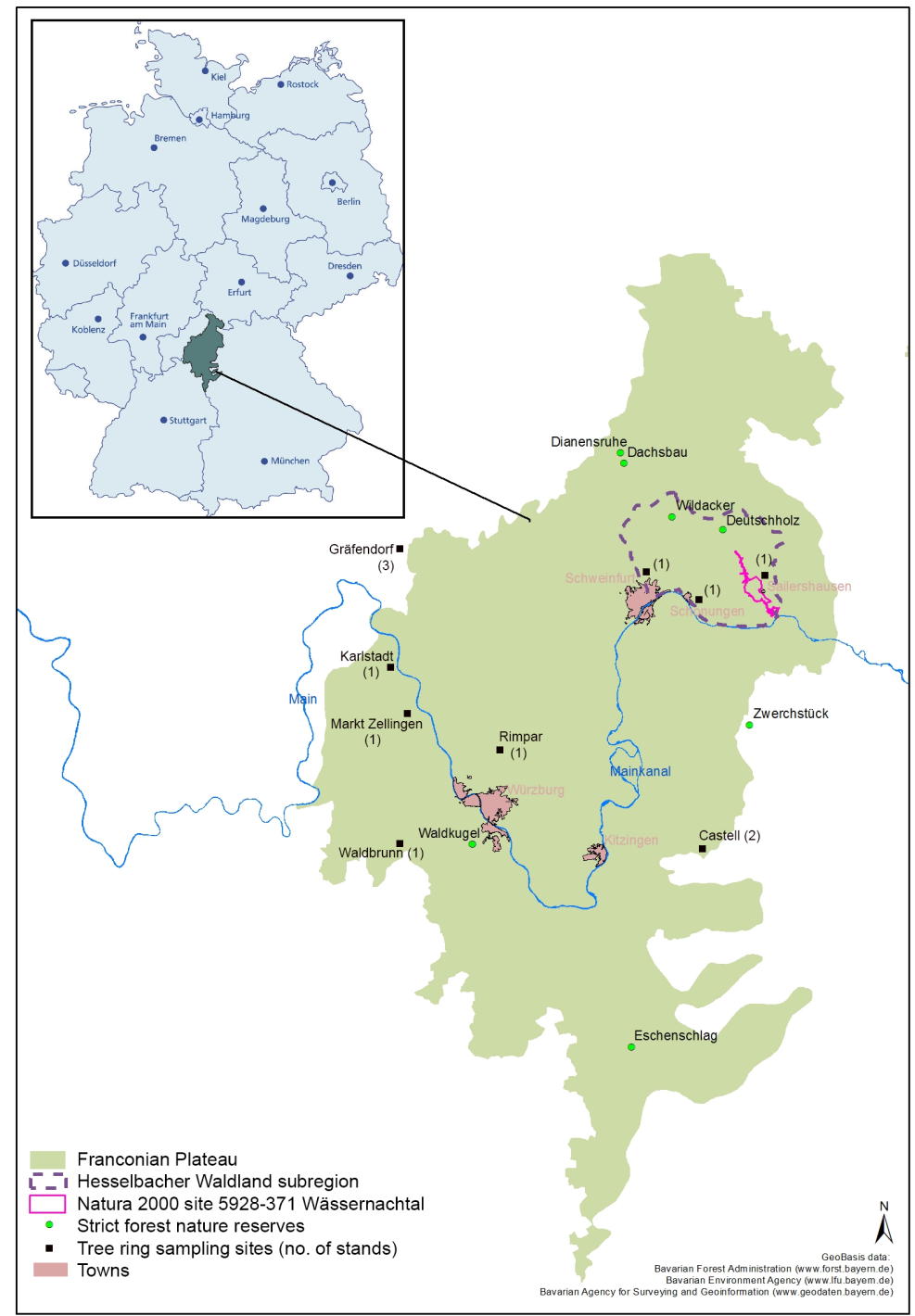

Figure 1 Map of the study area (inset: location of the Franconian Plateau in Germany)

ure 2) compared to the overall German forested area, due to its location in the rain shadow of mountain regions further west.

The analysis of the regional niche occupation of the species was based on vegetation plot (relevé) data from seven strict forest nature reserves (SFR; European Commission 2000, "Naturwaldreservate" in German) on or close to the Franconian Plateau (see figure 1). The seven selected sites are representative forest types of the Franconian Plateau, and are part of a network of reserves that has been established covering all major soil and forest community types in Bavaria (Walentowski et al. 2014). Since tree ring sampling was not permitted in the SFRs, increment cores for tree-ring analyses were collected from twelve typical stands dominated by $F$. sylvatica and $Q$. petraea. The 


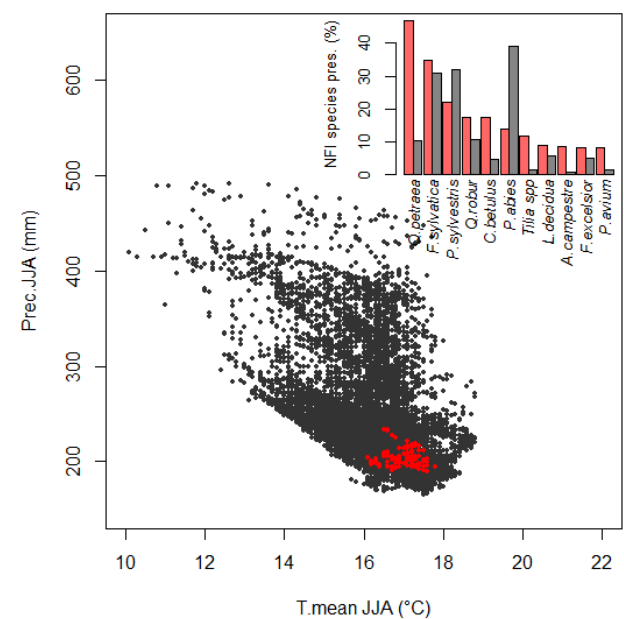

Figure 2 Ordination of the 3rd German national forest inventory (NFI) in a temperature-precipitation diagram (black dots: all NFI plots distributed on a 4 x $4 \mathrm{~km}$ grid across Germany, $\mathrm{N}=60,000$, red dots: NFI plots on the Franconian Plateau, $\mathrm{N}=$ 233). Upper right corner: species presence in the NFI for the 11 most abundant species on the Franconian Plateau (red: NFI Franconian Plateau, light grey: NFI entire Germany). Climate data: WorldClim (resolution 30 arcsec, period 1951-2000).

sites were located in elevations between 300 $560 \mathrm{~m}$ a.s.l. on rather shallow and dry silty to sandy soils covering different geological parent material, including limestones, sandstones, and loess. Despite the fact that the tree species compositions were moderately modified by previous stand history, the SFRs generally represent forest community types in accordance with the potential natural vegetation of Europe (Bohn et al. 2000-2003). They cover a broad spectrum of the typical regional forest community types and had not been managed for several years to decades prior to the data collection. Additionally to this study area, we used European inventory plots for species distribution analysis in order to cover most of the distribution range. The study area for this method is defined by the ICP-Forests monitoring plots on crown condition (Lorenz 1995).

\section{Climate data}

Climate data were taken from the WorldClim database (Hijmans et al. 2005) in the finest resolution available of 30 arcseconds $(\sim 1$ $\mathrm{km})$. The "current" climate data refer to the period 1951-2000, the future climates used in this study refer to the period 2061-2080 and are abbreviated as '2070'. Future data are 63 climate scenarios from 19 global climate models (GCMs) for four representative pathways (RCPs) according to the IPCC Fifth Assessment report (IPCC 2013). GCM data were provided by the Coupled Model Intercomparison Project Phase 5 (CMIP5) and downscaled and calibrated using WorldClim 1.4 'current' as the baseline by the WorldClim working group. For species distribution modelling we used the bioclimatic variables BIO6 (mininum temperature of coldest month), BIO10 (mean temperature of warmest quarter), and BIO18 (precipitation of warmest quarter) as input variables. The warmest quarter is thereby defined as any three consecutive months that are warmer than any other set of three consecutive months (Xu and Hutchinson 2011). Table 1 summarizes the current and projected temperature and precipitation data for our study area, the Franconian Plateau. There is no clear trend in summer precipitation (minus c. $9 \%$ on average over all scenarios for 2070 compared with 2000). Summer and minimum winter temperatures show an average increase over all scenarios of $3.5^{\circ} \mathrm{C}$ and $3.0^{\circ} \mathrm{C}$, respectively.

We also used the climate data to detect years with severe drought conditions, which were the basis for further tree ring analyses studying the impacts of drought on tree growth (see chapter 2.5). We calculated the Standardized Precipitation Evapotranspiration Index (SPEI) with the software R 2.15.0 using the package SPEI (Vicente-Serrano et al. 2010). Here, we defined drought events as periods during 
Table 1 Current and projected temperature and precipitation data for the study area, Franconian Plateau (regional average, Worldclim 1.4, 30 arcsec resolution, Hijmans et al. 2005). "Current" represents the periodic average of 1950-2000, "2070" a periodic average of 2061-2080. "2070" data were averaged for 15, 19, 12 and 17 atmospheric-oceanic global circulation models for RCP2.6, 4.5, 6.0 and 8.5, respectively (total $=63$ ).

\begin{tabular}{llllllll}
\hline Parameter & Unit & Current & $\begin{array}{l}2070 \\
\text { RCP2.6 }\end{array}$ & $\begin{array}{l}2070 \\
\text { RCP4.5 }\end{array}$ & $\begin{array}{l}2070 \\
\text { RCP6.0 }\end{array}$ & $\begin{array}{l}2070 \\
\text { RCP8.5 }\end{array}$ & $\begin{array}{l}2070 \text { all } \\
\text { RCPs }\end{array}$ \\
\hline $\begin{array}{l}\text { Mean annual temperature } \\
\text { (Bio01) }\end{array}$ & ${ }^{\circ} \mathrm{C}$ & 8.4 & 10.4 & 11.2 & 11.2 & 12.5 & 11.3 \\
\hline $\begin{array}{l}\text { Minimum temperature of } \\
\text { the coldest month (Bio06) }\end{array}$ & ${ }^{\circ} \mathrm{C}$ & -3.8 & -1.7 & -1.0 & -0.9 & 0.3 & -0.8 \\
\hline $\begin{array}{l}\text { Mean temperature of the } \\
\text { warmest quarter (Bio10) }\end{array}$ & ${ }^{\circ} \mathrm{C}$ & 16.8 & 19.1 & 20.2 & 20.1 & 21.8 & 20.3 \\
\hline $\begin{array}{l}\text { Annual sum of } \\
\text { precipitation (Bio12) }\end{array}$ & $\mathrm{mm}$ & 678 & 713 & 703 & 706 & 704 & 706 \\
\hline $\begin{array}{l}\text { Precipitation sum of the } \\
\text { warmest quarter (Bio18) }\end{array}$ & $\mathrm{mm}$ & 211 & 215 & 198 & 208 & 190 & 203 \\
\hline
\end{tabular}

which SPEI values were less than two standard deviation units below the mean for at least one year (Quiring 2009, Williams et al. 2013).

\section{Species distribution model}

We rated the suitability of a tree species to warmer future climates with the help of species distribution models (SDMs). We chose 18 tree species that were present both in the vegetation data (relevés) and in the European forest inventory data base of the ICP Forests international large-scale forest condition monitoring program (Level I plots; Lorenz 1995). The European perspective of our SDMs also includes warmer and potentially drier climates than the current climate in our smaller study area. It can therefore be used to estimate the suitability of tree species on the Franconian Plateau under present and future climate conditions.

Data from the year 2000 (matching with the WorldClim 'current' data) were transformed into presence/absence data and combined with vegetation map information on forest community types and their species composition (Bohn et al. 2000-2003) in order to correct for Level I plots with fallacious absence of species occurrence (Hirzel \& Le Lay 2008). Fallacious absence refers to plots without species occur106 rence due to other reasons than unfavorable site conditions (e.g. management). Additionally, the correction was applied because the distribution models aim at describing the potential distribution of a species rather than the real distribution caused by management effects. The combination of inventory data with vegetation map data aims at providing the most comprehensive picture of a species distribution under forest management. In case of rare broadleaved species (Acer, Sorbus, Tilia, Ulmus), presences and therefore models are mainly influenced by the vegetation data set and not by the inventory data. They therefore reflect vegetation experts' opinion on distribution. The final data set consisted of 5,914 plots covering Europe with the exception of eastern parts of Russia and Ukraine. In the case of Pinus sylvestris L. and Populus tremula L., 75 $\%$ of the plots north of $52^{\circ} \mathrm{N}$ and east of $5^{\circ}$ $\mathrm{E}$ were filtered because models would respond principally to the strong presence of Scots pine in these cold regions and the distribution edge in a warmer climate was not described well. This resulted in 3,859 plots for these two species.

Species data were combined with climate data from the WorldClim data base, using BIO6, 10 and 18 following Mellert et al. 
(2015). Distribution modelling was done for each species separately using generalized additive models (GAMs; Wood \& Augustin 2002, Wood 2006) using the R package $m g c v$ 1.8-6 (Wood 2011). Models were calibrated with the full data set, but quality measures were obtained with multiple data-splitting (as implemented in biomod; Thuiller et al. 2009): $70 \%$ were chosen as calibration data and 30 $\%$ as validation data. We averaged 100 split data runs and calculated the following quality measures (Freeman \& Moisen 2008a): Percent correctly classified plots (PCC), Sensitivity, Specificity, Kappa, and AUC value (area under the [receiver operating] curve). Models with a very low Kappa value or very low presence rates are likely to be unreliable (Freeman \& Moisen 2008b).

We used thin plate regression splines (Wood 2006) for the generalized additive modelling. The general formula of the distribution model was

Species $_{p / a}=s(B I O 6)+t e(B I O 10, B I O 18)$

with $<_{s}>$ for a simple spline smooth of BIO06 and $\langle t e\rangle$ the tensor product of $\mathrm{BIO} 10$ and $\mathrm{BIO18}$. The degree of smoothness in the package $m g c v$ is estimated by a generalized cross validation $(\mathrm{GCV})$ criterion within certain limits set by, for example, the dimension $\mathrm{k}$ of the basis used to represent the smooth term. For BIO6, k-values were first set to 4 and reduced to 3 for 5 species (Betula pendula Roth, Prunus avium, Populus tremula, Quercus robur, Tilia cordata) in order to meet assumptions on physiological plausibility checked against single response curves (Austin \& Gaywood 1994). These values affect the maximum possible degree of freedom for each term of the GAM.

In order to rate the species according to the match between climate conditions and assumed physiological growth potential, we computed model predictions for recent and future climates at 19 sites on and close to the Franconian Plateau and transformed them into favorability estimations according to Real et al. (2006). Predictions were averaged over all 63 climate scenarios of the WorldClim data base (in case of future climate) and over the 19 sites used in this study (seven forest reserves with relevés and 12 stands with tree ring measurements, see figure 1), resulting in one favorability score for the current climate and one for the future. Standard deviations for current favorability are based on averaging the 19 sites, those for the future on averaging the 63 scenario outcomes and afterwards calculating a mean SD over the 19 sites. The former is a measure for the statistical spread between the sites and the latter for the spread between the scenario outcomes.

\section{Fine-scale ecological niche analysis}

We analyzed vegetation data (51 relevés) from seven selected strict forest reserves of the Franconian Plateau extracted from the vegetation-plot data base of the Bavarian State Institute of Forestry (Abs et al 2008; table 2). We compared the vegetation plot data with a comprehensive study by Hofmann (1964/65) on the vegetation ecology of the deciduous forests of the Franconian Plateau to confirm that it is representative for the study area. Data collection, sample processing and data analysis followed phytosociological methods as described in Dierschke (1994). The grouping results were verified by numerical cluster analysis (minimum variance, Ward 1963) and Indicator Species Analysis (Dufrêne \& Legendre 1997). For cluster analysis, the skewed distributed cover values were transformed to normalized distribution following Pudlatz (1975).

We assigned the relevés to nationally and internationally valid vegetation types (syntaxa) following vegetation classification manuals for southern Germany (Oberdorfer et al. 1992), Germany (Härdtle et al. 2004) and Europe (Bohn et al. 2000-2003). We applied Detrended Correspondence Analysis (DCA) to analyze variation in species compositions, species turnover (from the main matrix) and struc- 
Table 2 Data from seven strict forest reserves of the Franconian Plateau extracted from the vegetation-plot database of the Bavarian State Institute of Forestry (LWF)

\begin{tabular}{|c|c|c|c|c|c|c|c|}
\hline $\begin{array}{l}\text { Characte- } \\
\text { ristics }\end{array}$ & $\begin{array}{l}\text { Eschen- } \\
\text { schlag }\end{array}$ & Dianensruhe & Dachsbau & $\begin{array}{l}\text { Deutsch- } \\
\text { holz }\end{array}$ & Wildacker & $\begin{array}{l}\text { Zwerch- } \\
\text { stück }\end{array}$ & Waldkugel \\
\hline $\begin{array}{l}\text { Year of } \\
\text { designation }\end{array}$ & 1978 & 1978 & 1978 & 1978 & $\begin{array}{l}1978 \\
\text { (enlarged } \\
1998 \text { ) }\end{array}$ & 1998 & 1999 \\
\hline Area (ha) & 8.1 & 22.2 & 28.4 & 9.7 & 16.4 & 27.9 & 73.8 \\
\hline $\begin{array}{l}\text { Altitude } \\
\text { range (m } \\
\text { a.s.1.) }\end{array}$ & $388-395$ & $310-353$ & $290-357$ & $355-370$ & $335-360$ & $320-350$ & $230-290$ \\
\hline $\begin{array}{l}\text { Prevailing } \\
\text { vegetation }\end{array}$ & $\begin{array}{l}\text { ash-oak- } \\
\text { mixed forest } \\
\text { (former } \\
\text { coppice with } \\
\text { standards) } \\
\end{array}$ & $\begin{array}{l}\text { oak-hornbeam- } \\
\text { forest }\end{array}$ & $\begin{array}{l}\text { species- } \\
\text { rich former } \\
\text { coppice } \\
\text { with } \\
\text { standards } \\
\end{array}$ & $\begin{array}{l}\text { oak- } \\
\text { hornbeam- } \\
\text { forest }\end{array}$ & $\begin{array}{l}\text { species-rich } \\
\text { deciduous } \\
\text { mixed forest }\end{array}$ & $\begin{array}{l}\text { oak- } \\
\text { hornbeam- } \\
\text { forest }\end{array}$ & $\begin{array}{l}\text { beech } \\
\text { forests }\end{array}$ \\
\hline $\mathrm{T}(\mathrm{a})\left({ }^{\circ} \mathrm{C}\right)$ & 8.5 & 8.2 & 8.2 & 8.2 & 8.2 & 8.1 & 8.5 \\
\hline $\mathrm{T}$ (veg) $\left({ }^{\circ} \mathrm{C}\right)$ & 15.3 & 15 & 15 & 15 & 15 & 14.9 & 15.3 \\
\hline $\mathrm{P}(\mathrm{a})(\mathrm{mm})$ & 669 & 690 & 690 & 690 & 690 & 716 & 669 \\
\hline $\mathrm{P}(\mathrm{veg})(\mathrm{mm})$ & 312 & 310 & 310 & 310 & 310 & 332 & 312 \\
\hline Geology & $\begin{array}{l}\text { Pleistocene } \\
\text { and Middle } \\
\text { Keuper }\end{array}$ & $\begin{array}{l}\text { Lower Middle } \\
\text { Triassic } \\
\text { limestone }\end{array}$ & $\begin{array}{l}\text { Lower } \\
\text { Middle } \\
\text { Triassic } \\
\text { limestone }\end{array}$ & Keuper & $\begin{array}{l}\text { Pleistocene } \\
\text { and Upper } \\
\text { Middle } \\
\text { Triassic } \\
\text { limestone }\end{array}$ & $\begin{array}{l}\text { Lower } \\
\text { Keuper }\end{array}$ & $\begin{array}{l}\text { Upper } \\
\text { Middle } \\
\text { Triassic } \\
\text { limestone } \\
\text { and Lower } \\
\text { Keuper }\end{array}$ \\
\hline
\end{tabular}

Date of

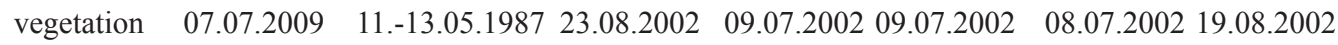
survey

\begin{tabular}{llllllll}
\hline $\begin{array}{l}\text { Relevé area } \\
\left(\mathrm{m}^{2}\right)\end{array}$ & 200 & $200-400$ & $100(200)$ & $100-200$ & $100-200$ & $100-200$ & $100-200$ \\
\hline $\begin{array}{l}\text { Number of } \\
\text { relevés }\end{array}$ & 6 & 20 & 7 & 4 & 4 & 6 & 4 \\
\hline
\end{tabular}

Note. Abbreviations: T(a) - mean annual temperature, $\mathrm{T}(\mathrm{veg})$ - mean temperature during vegetation period (May-September), $\mathrm{P}(\mathrm{a})$ - annual precipitation and $\mathrm{P}(\mathrm{Veg})$ - precipitation during vegetation period (May-September).

tural and environmental variables (from the second matrix). The efficacy of this technique has been well established (Okland 1996). Using PC-ORD 6.0 MjM Software (Gleneden Beach, OR, USA), we carried out detrending by segments (default of 26 segments) and did not downweight rare species, because important indicator tree species may be rare in the data set. The cover values of the main matrix were modified by power transformation (Mc108
Cune \& Grace 2002) before analysis. For species occurring in several layers, the maximum cover was always used.

The variables of the second matrix, used as passive variables, were not transformed. In the second matrix, we included the vegetation type as a categorical variable and seven quantitative variables including the species number and the ordinal scaled Ellenberg indicator values (EIVs; Ellenberg et al. 2001). EIVs use 
numerical values to express the average realized niches along six fundamental gradients (light availability [L], temperature [T], continentality $[\mathrm{K}]$, soil moisture $[\mathrm{F}]$, soil reaction or $\mathrm{pH}[\mathrm{R}]$, nutrients $[\mathrm{N}]$ ). While the limitations and strengths of Ellenberg's approach have long been debated (e.g. Weber 2003), a number of studies showed good agreement between indicators and environmental variables (e.g., Schaffers \& Sýkora 2000, Schmidtlein \& Ewald 2003, Fanelli et al. 2007). Since we analysed species-rich communities, we calculated unweighted mean EIVs for all species in a relevé (cf. Melman et al. 1988, Schaffers \& Sýkora 2000, Ellenberg et al. 2001). In combination with Pearson correlation analyses, presumed influences of environmental factors on species combinations were visualized. As proposed by Zelený \& Schaffers (2012), we refrained from testing the significance of these correlations, since variables deduced from species compositions are dependent variables.

After classification, ordination and ecological interpretation of the forest types, we assigned the 19 tree species present in the vegetation data to the ecological groups by performing indicator species analysis. The indicator values $(I V)$ were calculated with the method of Dufrêne \& Legendre (1997). The ecological site classification (ESC) by plant indicator species followed Ewald (2007). Finally, we analysed the correlation of the tree species to substrate type and water soil regime of the regional forest sites by application of a non-parametric Kruskal-Wallis $H$-test $(K W$ $H)$. The soil moisture categories used here are translations of the Bavarian forest site mapping classification system (Walentowski et al. 2013;).

\section{Tree ring analysis}

We analyzed tree ring data from 12 deciduous forest stands on the Franconian Plateau in six different locations (figure 1 and Supporting Information 3, table 9). We collected increment cores from 15 dominant trees in two stands (Sailershausen and Schonungen) dominated by $F$. sylvatica and $Q$. petraea, with additional admixed broadleaf species (described in section 2.1), including the minor tree species $S$. torminalis, Acer platanoides L., and A. campestre. Pairwise sampling (Bigler \& Bugmann 2003) was applied by selecting one individual of one of the two main tree species $(Q$. petraea, F. sylvatica) and one individual of a minor species. This approach ensures both an adequate number of sample trees and a better comparability of the results between major and minor tree species, although $A$. platanoides was only present at one of the two study sites. For every species and site, at least 10 (co-)dominant and healthy trees were selected as sample trees (Dittmar et al. 2003). To strengthen the validity of the dendroecological results, ten additional forest sites with $Q$. petraea and F. sylvatica tree-ring data (Meinardus \& Bräuning 2011, Zang et al. 2011) were included in the analyses, giving a total of 12 studied stands (figure 1). Although no pairwise sampling approach was used in these studies, all other tree selection and sampling criteria were comparable. Overall, the total number of analyzed trees was: Quercus petraea $=132$, Fagus sylvatica $=131$, Acer campestre $=18$, Sorbus torminalis $=17$, Acer platanoides $=$ 9. The low number of potential sample trees for the minor broadleaves is not only limited by the rare occurrence of the species (Hemery 2008), but the risk of wood discoloration or decay after coring (Kunz et al. 2011) leading to significant decreases in timber value (Schrötter 2001). Two increment cores were taken from each tree at breast height $(1.3 \mathrm{~m})$ in southern and eastern cardinal directions. Subsequently, the cores were dried, planed, and ring-width was measured to an accuracy of the nearest $0.01 \mathrm{~mm}$ using a Lintab digital positioning table (Rinntech, Heidelberg, Germany) using TSAP software (Rinntech, Heidelberg, Germany). This measurement approach generates very precise results and is often used in den- 
drochronological and - ecological studies (e.g. Eilmann et al. 2006, Bouriaud \& Popa 2009, Gillner et al. 2014, Zang et al. 2014). Individual tree ring series were cross-dated visually and with an interval sign test (Schweingruber 1988). Ring series that could not be synchronized were removed from further analyses. To remove biological age trends, but to retain decadal climate variability, the raw ring-width measurements were detrended by applying a smoothing spline function with a $50 \%$ frequency cut-off at $2 / 3$ of the series lengths (Cook \& Kairiukstis, 1990). Site chronologies were built for each tree species using Tukey's biweight robust mean. Additionally, mean sensitivity (MS), the cross-correlation between single series (Rbar), and the expressed population signal (EPS) were calculated to control the accuracy of the site chronologies (Fritts 1976, Wigley et al. 1984). Detrending and chronology were carried out with the software $R 2.15 .0$ using the package $d p l R$ (Bunn 2008). For a detailed analysis of tree response to water shortage, the radial growth of the focal tree species was surveyed in drought years 1947, 1976, and 2003, which were detected by the calculated SPEI data and which are known as severe trans-regional event years (Dittmar et al. 2012, Zang et al. 2011). Therefore, a superposed epoch analysis (SEA) was performed for each tree ring chronology with 10,000 bootstrapped resamples and 5-year lag before and after the drought events (Bunn 2008). Tolerance indices for resistance and recovery were calculated for every drought year and focal species using a five year reference window (Lloret et al. 2011). Significant differences between species were revealed with a one-way analysis of variance $(\mathrm{p}<0.05)$.

\section{Results}

\section{Species distribution models}

Figure 3 illustrates the modelled climatic niches for five key species $-A$. campestre, $A$. 110 platanoides, F. sylvatica, Q. petraea and $S$. torminalis - according to the species distribution models (SDMs). The nominal favorability scores range between 0 and 1 (low to high) with values $>0.5$ indicating climatically suitable sites for a given tree species. The present climate of the Franconian Plateau (green dots) still lies well within the predicted distribution range of the five species. However, the species show different "buffers" towards warmer and drier climates, which makes them more or less vulnerable to the expected future climate conditions in the region (red squares). Based on the shape of its suitable climate (black lines in figure 3), the least adapted species is A. platanoides: once the average temperature of the warmest quarter exceeds ca. $19^{\circ} \mathrm{C}\left(2{ }^{\circ} \mathrm{C}\right.$ higher than currently), no amount of additional precipitation can compensate and the species is likely to decline. If additionally the minimum temperature of coldest month (BIO6) is taken into account, 55 of 63 are outside the climatic distribution limit (predictions below 0.5). Thus, there is an $87 \%$ probability of threshold exceedance. $F$. sylvatica is assumed to persist under somewhat higher temperatures, especially if precipitation increases. Still, 28 of the 63 scenarios lie outside its modelled temperature-precipitation limits (44\% probability of threshold exceedance). For Q. petraea only 12 scenarios exceed its climatic range (19\%), for $S$. torminalis only $3(5 \%)$, and $A$. campestre is not temperature limited at all.

An overview of the species distribution models for all 18 species considered is given in table 3 , including the calculated model predictions (favorabilities), the Ellenberg indicator value for moisture (EIV-F), and the drought tolerance score after Niinemets \& Valladares (2006). Quality measures for the models are given in Supporting Information 1 table 5, maps of the model output for all species in Supporting Information 1 figure 7.

Under current climate conditions, SDM scores rank $Q$. petraea, $Q$. robur and F. sylvatica very high, but also $C$. betulus and Tilia spp. The higher temperatures in the future sce- 

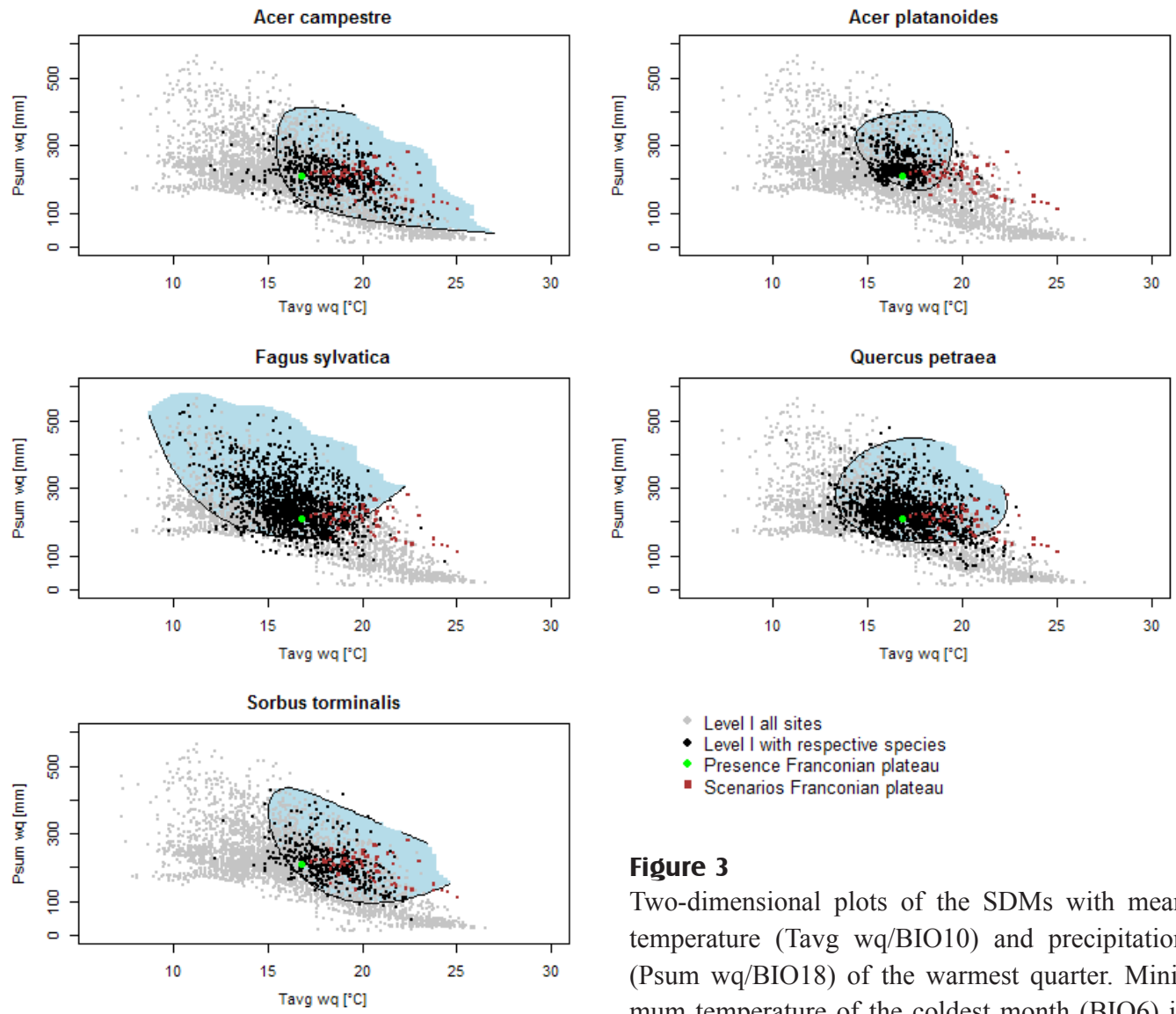

$$
\begin{aligned}
& \text { - Level I all sites } \\
& \text { - Level I with respective species } \\
& \text { - Presence Franconian plateau } \\
& \text { - Scenarios Franconian plateau }
\end{aligned}
$$

\section{Figure 3}

Two-dimensional plots of the SDMs with mean temperature (Tavg wq/BIO10) and precipitation (Psum wq/BIO18) of the warmest quarter. Minimum temperature of the coldest month (BIO6) is set to mean value 1951-2000 of the species presences in the European data used for SDMs. Colored area is suitable for the species, threshold 0.5. Extrapolation area is masked. Grey dots show complete Level I data, black dots the presences of the species. The green dot is the mean value of Franconian Plateau (1951-2000), brown squares are the mean values for 63 WorldClim scenarios 2061-2080.

narios change the favorability patterns and reveal which species are adapted to warmer and potentially drier conditions: A. campestre, $U$. minor, $S$. torminalis and $S$. aria, $Q$. petraea, C. betulus, T. platyphyllos as well as $P$. avium have the highest favorabilities, i.e. greater than 0.5 averaged over the examined future climate scenarios. A. campestre and U. minor even maintain high favorabilities over all scenarios. A second group of species with favorability scores between 0.42 and 0.52 includes $Q$. robur, F. sylvatica, F. excelsior, and P. tremula. Especially the moderate climate change sce- narios still qualify them as suitable species for silviculture. A third group of species presumably reaches their climatic distribution thresholds earlier: A. pseudoplatanus, T. cordata, $B$. pendula, $P$. sylvestris, and A. platanoides.

\section{Natural forest reserves: niche divergence}

The first axis of the DCA had an eigenvalue of 0.62 and explained $49 \%$ of the variation in the DCA ordination space. Only very few species were shared at the opposite ends of the gradient, i.e. there was high beta diversity. 
Table 3 Summary table for 18 of the tree species considered in this study, including \% of plots in the NFI data for the Franconian Plateau area in which the species is present, the indicator species analysis results (groups cf. figure 5), the species distribution model results for the current WorldClim climate data (1951-2000) and the average of 63 future climate scenarios (for the period 2061-2080, abbreviated as 2070), and the dendrochronological results of significant growth decline.

\begin{tabular}{|c|c|c|c|c|c|c|c|c|c|c|c|}
\hline \multirow[t]{2}{*}{ Species } & \multirow{2}{*}{$\begin{array}{l}\text { NFI 2012, } \\
\text { Franconian } \\
\text { Plateau } \\
\\
\text { Presence } \\
(\%)\end{array}$} & \multirow{2}{*}{$\begin{array}{l}\text { Indicator } \\
\text { species } \\
\text { analysis } \\
\\
\text { DCA } \\
\text { group }\end{array}$} & \multicolumn{2}{|c|}{$\begin{array}{l}\text { Species } \\
\text { distribution } \\
\text { model. } \\
\text { Favorability } \\
( \pm \text { SD) in year }\end{array}$} & \multicolumn{3}{|c|}{$\begin{array}{l}\text { Tree ring analysis } \\
\text { Number of plots } \\
\text { with sign. growth } \\
\text { decline/total } \\
\text { number of plots }\end{array}$} & \multirow[t]{2}{*}{$\begin{array}{l}\begin{array}{l}\text { Drought } \\
\text { tolerance }\end{array} \\
\text { (Niinemets } \\
\& \\
\text { Valladares } \\
2006)\end{array}$} & \multicolumn{3}{|c|}{$\begin{array}{l}\text { Ellenberg } \\
\text { indicator } \\
\text { value }\end{array}$} \\
\hline & & & 2000 & 2070 & 1947 & 1976 & 2003 & & $\mathrm{~T}$ & $\mathrm{~L}$ & $\mathrm{~F}$ \\
\hline Acer campestre & 8.6 & I/III & $\begin{array}{c}\mathbf{0 . 6 9} \\
(0.04)\end{array}$ & $\begin{array}{c}\mathbf{0 . 9 1} \\
(0.06)\end{array}$ & $0 / 2$ & $1 / 2$ & $1 / 2$ & 2.93 & 6 & 5 & 5 \\
\hline Ulmus minor & $*$ & I & $\begin{array}{c}\mathbf{0 . 6 5} \\
(0.08)\end{array}$ & $\begin{array}{c}\mathbf{0 . 8 9} \\
(0.06)\end{array}$ & - & - & - & 3.39 & 7 & 5 & $\mathrm{x}$ \\
\hline Sorbus torminalis & 1.7 & I & $\begin{array}{c}\mathbf{0 . 6 7} \\
(0.08)\end{array}$ & $\begin{array}{c}\mathbf{0 . 8 4} \\
(0.13)\end{array}$ & $0 / 2$ & $1 / 2$ & $0 / 2$ & 3.74 & 7 & 4 & 4 \\
\hline Sorbus aria & 0.4 & I & $\begin{array}{c}\mathbf{0 . 6 1} \\
(0.06)\end{array}$ & $\begin{array}{c}\mathbf{0 . 7 7} \\
(0.13)\end{array}$ & - & - & - & 3.55 & 5 & 6 & 4 \\
\hline Quercus petraea & 46.8 & I-II & $\begin{array}{c}\mathbf{0 . 8 9} \\
(0.03)\end{array}$ & $\begin{array}{c}\mathbf{0 . 7 3} \\
(0.25)\end{array}$ & $0 / 11$ & $1 / 11$ & $0 / 11$ & 3.02 & 6 & 6 & 5 \\
\hline Carpinus betulus & 17.6 & I-II & $\begin{array}{c}\mathbf{0 . 7 2} \\
(0.03)\end{array}$ & $\begin{array}{c}\mathbf{0 . 6 8} \\
(0.19)\end{array}$ & - & - & - & 2.66 & 6 & 4 & $\mathrm{x}$ \\
\hline Tilia platyphyllos & $*$ & I & $\begin{array}{c}\mathbf{0 . 7 0} \\
(0.03)\end{array}$ & $\begin{array}{c}\mathbf{0 . 6 8} \\
(0.23)\end{array}$ & - & - & - & 2.52 & 6 & 4 & 5 \\
\hline Prunus avium & 8.2 & h & $\begin{array}{c}\mathbf{0 . 6 7} \\
(0.05)\end{array}$ & $\begin{array}{c}\mathbf{0 . 6 8} \\
(0.32)\end{array}$ & - & - & - & 2.66 & 5 & 4 & 5 \\
\hline Quercus robur & 17.6 & III & $\begin{array}{c}\mathbf{0 . 8 1} \\
(0.01)\end{array}$ & $\begin{array}{c}\mathbf{0 . 5 2} \\
(0.27)\end{array}$ & - & - & - & 2.95 & 6 & 7 & $\mathrm{x}$ \\
\hline Fagus sylvatica & 34.8 & II & $\begin{array}{c}\mathbf{0 . 7 9} \\
(0.04)\end{array}$ & $\begin{array}{c}\mathbf{0 . 5 2} \\
(0.29)\end{array}$ & $1 / 10$ & $7 / 10$ & $2 / 10$ & 2.4 & 5 & 3 & 5 \\
\hline $\begin{array}{l}\text { Fraxinus } \\
\text { excelsior }\end{array}$ & 8.2 & III & $\begin{array}{c}\mathbf{0 . 7 0} \\
(0.01)\end{array}$ & $\begin{array}{c}\mathbf{0 . 4 6} \\
(0.20)\end{array}$ & - & - & - & 2.5 & 5 & 4 & $\mathrm{x}$ \\
\hline Populus tremula & 1.7 & h & $\begin{array}{c}\mathbf{0 . 5 5} \\
(0.01)\end{array}$ & $\begin{array}{c}\mathbf{0 . 4 5} \\
(0.19)\end{array}$ & - & - & - & 2.85 & 5 & 6 & 5 \\
\hline $\begin{array}{l}\text { Acer } \\
\text { pseudoplatanus }\end{array}$ & 5.2 & II & $\begin{array}{c}\mathbf{0 . 6 5} \\
(0.05)\end{array}$ & $\begin{array}{c}\mathbf{0 . 3 0} \\
(0.22)\end{array}$ & - & - & - & 2.75 & $\mathrm{x}$ & 4 & 6 \\
\hline Tilia cordata & $*$ & III & $\begin{array}{c}\mathbf{0 . 7 0} \\
(0.02)\end{array}$ & $\begin{array}{c}\mathbf{0 . 2 5} \\
(0.22)\end{array}$ & - & - & - & 2.75 & 5 & 5 & 5 \\
\hline Betula pendula & 7.7 & h & $\begin{array}{c}\mathbf{0 . 6 5} \\
(0.02)\end{array}$ & $\begin{array}{c}\mathbf{0 . 2 3} \\
(0.18)\end{array}$ & - & - & - & 1.85 & $\mathrm{x}$ & 7 & $\mathrm{x}$ \\
\hline Pinus sylvestris & 21.9 & II & $\begin{array}{c}\mathbf{0 . 6 2} \\
(0.04)\end{array}$ & $\begin{array}{c}\mathbf{0 . 2 1} \\
(0.16)\end{array}$ & - & - & - & 4.34 & $\mathrm{x}$ & 7 & $\mathrm{x}$ \\
\hline Acer platanoides & 1.3 & II & $\begin{array}{c}\mathbf{0 . 6 6} \\
(0.03)\end{array}$ & $\begin{array}{c}\mathbf{0 . 2 0} \\
(0.22)\end{array}$ & $0 / 1$ & $0 / 1$ & $1 / 1$ & 2.73 & 6 & 4 & $\mathrm{x}$ \\
\hline Larix decidua & 9.0 & h & $\begin{array}{c}\mathbf{0 . 3 7} \\
(0.06)\end{array}$ & $\begin{array}{c}\mathbf{0 . 0 5} \\
(0.08)\end{array}$ & - & - & - & 2.31 & $\mathrm{x}$ & 8 & 4 \\
\hline
\end{tabular}

Note. For comparison, the drought tolerance index (Niinemets and Valladares 2006; 0 - low, 5 - high) and the Ellenberg indicator values for temperature (T, 1 - low, 9 - high, $\mathrm{x}$ - indifferent), light (L, values refer to saplings), moisture (F) are also given. Species are ordered according to decreasing favorability in the year 2070. Species names of weaker models are grey (cf. Supp. Info. 1, table 5), key species names are bold. *Linden species Tilia cordata and Tilia platyphyllos and elm species Ulmus minor, U. glabra and U. laevis were not differentiated in the NFI 2012. Tilia spp. occur on $11.6 \%$ of the plots, Ulmus spp. on $1.3 \%$. 
The axis is constituted mainly by soil moisture (EIV-F: $r=0.93)$, nutrient supply (EIV-N: $r=$ 0.73 ), and temperature (EIV-T: $r=-0.49$ ). The species turnover along the first axis was confirmed by the results of the Indicator Species Analysis, where numerous species were either restricted to warm and relatively dry (17 ISA indicator species) or to cool-humid and fertile sites (15 ISA indicator species) (Supporting Information 2.2, table 6). The second axis had an eigenvalue of 0.23 and explained another $8 \%$ of the variation in the DCA ordination space. The species turnover along the second axis was apparently related to light availability (EIV-L: $r=-0.57)$, continentality (EIV-K: $\mathrm{r}=-0.51$ ), and also nutrient supply (EIV-N: $r$ $=0.41)$. Moreover, the total number of species was negatively correlated with the second axis $(\mathrm{r}=-0.46)$.

The classification and hierarchical clustering of the vegetation data resulted in the following basic forest vegetation types of deciduous woodland of central Europe (Fagetalia sylvaticae), which may be further subdivided (figure 4, see also Supporting Information 2.1, 2.2 and 2.3): (I) Moderately xerophilous type: subcontinental oak-hornbeam-forest on limestone plateau (Galio-Carpinetum primuletosum veris); (II) Mesophilous types: (a) subcontinental oak-hornbeam forest on meso-

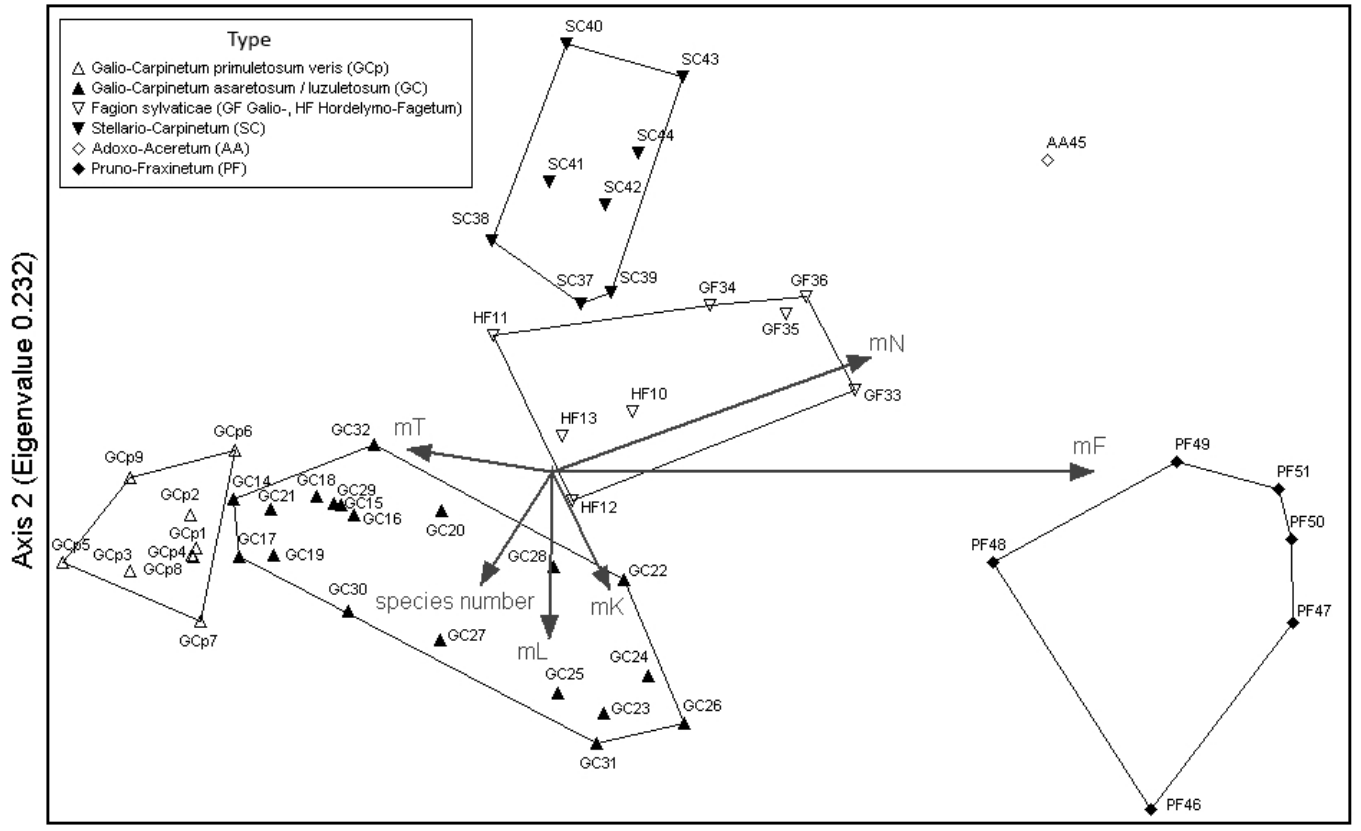

Axis 1 (Eigenvalue 0.617)

Figure 4 DCA diagram of 51 relevés recorded in 7 strict forest reserves of the Franconian Plateau (Eschenschlag, Dianensruhe, Dachsbau, Deutschholz, Wildacker, Zwerchstück and Waldkugel). Ordination of the plots is based on transformed cover values of in total 188 species and is presented as a joint plot with environmental variables (cutoff $r 2$ value: 0.20 ). The unweighted mean Ellenberg indicator values for light availability (EIV-mL), temperature (EIV-mT), continentality (EIV-mK), soil moisture $(E I V-m F)$, and nutrients $(E I V-m N)$ as well as species number were used as passive variables and therefore did not affect the DCA axis. Length of gradients: DCA-axis 1 = 4.014 SD, DCA-axis $2=2.495 \mathrm{SD}(\mathrm{SD}=$ standard deviation). 
phytic sites of different trophic levels (G.-C. asaretosum and luzuletosum); (b) subatlantic oak-hornbeam-forest on mesophytic sites of different trophic level (Stellario-Carpinetum typicum and stachyetosum), (c) medio-European beech forests on mesophytic sites of different trophic levels (Galio- and Hordelymo-Fagetum), (III) Hygrophilous types; ash forests on moist to wet, eutrophic habitats, rich in fine soil (Adoxo-Aceretum and Pruno-Frax- inetum).

The position of tree species in the DCA species ordination diagram (figure 5) and specific tree species responses along the first and second axis (Supporting Information 2.5) allowed us to classify four tree species grouping types (I, II, III and h) and two transition types (III and I/III), validated by the indicator value and the significance of the tree species for the given grouping types (Supporting Information

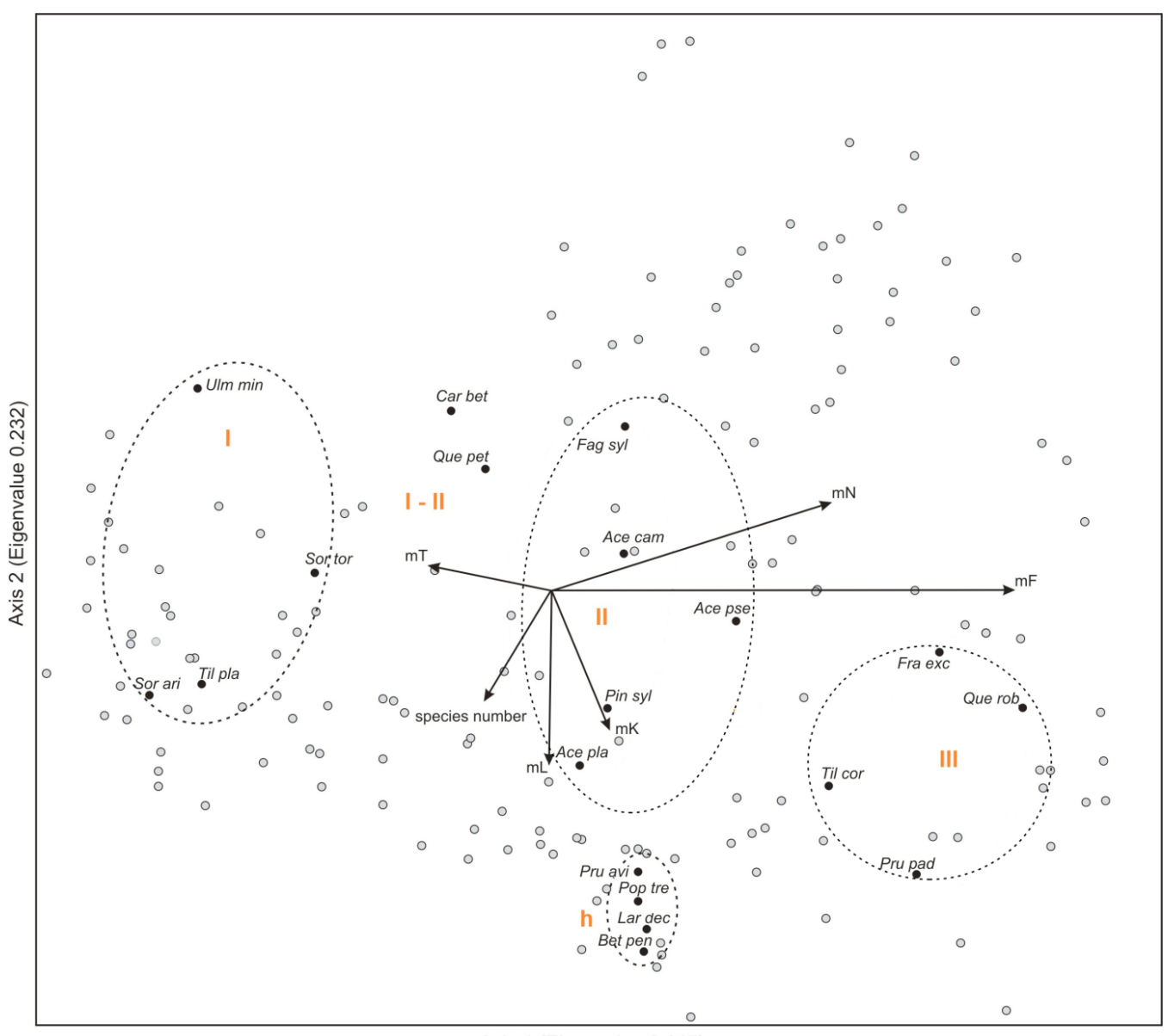

Axis 1 (Eigenvalue 0.617)

Figure 5 DCA diagram of species scores and an overlay of environmental factors (cutoff r2 value: 0.20 ). Length of gradients: DCA-axis $1=4.014 \mathrm{SD}$, DCA-axis $2=2.495 \mathrm{SD}$ (SD = standard deviation). Filled circles are the 19 tree species found in the relevés (see Supporting Information 2.1 for the full names), open circles are the 169 non-woody species. Tree species groupings and their transitions along the first axis are indicated by Roman numerals (group I, II and III; group transition I-II), tree species groupings along the second axis are given in small letters (h for heliophilous). 
2.4, table 7).

The first group (I) of the DCA ordination includes tree species on warm and skeleton-rich soils of shallow to moderate depth, dry Rendzina-Terra fusca soils on the Triassic limestone plateau with high drought risk. We identified T. platyphyllos and S. aria as the most reliable indicator species of this group. Even S. torminalis was a weakly significant indicator of dry soils, but was less abundant and frequent and was more broadly distributed on different substrates.

The semi-mesophilous transitional group (I - II $[\mathrm{a}, \mathrm{b}]$ ) was indicated by $Q$. petraea and C. betulus. Their ecological amplitudes ranged from dry to moist soil and were negatively correlated with humus-carbonate soils.

The central group (II) of tree species for mesophilous site conditions grew mainly on soils derived from loess-loam and clay marls, indicated by $F$. sylvatica and A. pseudoplatanus, the latter was identified as a rather hygro-mesophilous species (cf. Supporting Information 2.1 and 2.3). A. platanoides was almost entirely limited to the understory (cf. Supporting Information 2.1), and seedlings were found in all ordination groups, indicating relative indifference to the soil conditions. However, its relative abundance and relative frequency was higher in mesophilous types. A. platanoides was therefore also assigned to central group II, though its indicator value was low and not significant.

Finally, the third species group (III) showed a marked affinity to wetter soils, combined with high silt-loam and clay content (waterlogged bottomland soils or foot slopes percolated with moving water). These fertile but often relatively cool sites are prone to late frost, in particular if situated in hollows and valleys. Group III consisted of F. excelsior and $Q$. robur. $T$. cordata indicated damp to wet conditions. $T$. cordata and T. platyphyllos thus occupied contrasting niches. The former was identified as an indicator for group III with a weak positive trend to silt-loam substrates, and was positively correlated with lower dominance on damp and high dominance on waterlogged soils. However, T. platyphyllos as a reliable indicator of group I was positively correlated to calcareous loam substrates with dry to moist, well-drained soil. Similarly, the two oak species $Q$. robur and $Q$. petraea differed in their ecological behavior. The former showed a distinct focus on bottomland soils, rich in fine earth, and often waterlogged. The latter occurred on different substrates, and was even dominant on muddy marls of Lower Keuper with dry to moist soils, but rarely grew on very dry humus-carbonate soils and on waterlogged bottomland soils.

A special case is A. campestre (group I / III). The scatter plot of species scores (figure 5) suggested that it belongs to the mesophilous group, but this conflicted with its tree species-related overlay with the main matrix (Supporting Information 2.4, table 7 and 2.5). In fact, the mean positioning was caused by a bimodal distribution, with its ecological optimum on dry soils, and a secondary occurrence on wet soils (with a far lower growth capacity). The same is true to a lesser extent for $F$. excelsior and $Q$. robur, which are characteristic for wetter soils, but also occur in small numbers in xero-thermophilous sites (see Supporting Information 2.5). The last group of tree species was clustered at the lower end of the second axis (figure 5 and Supporting Information 2.5) including heliophilous species such as $B$. pendula, P. tremula, L. decidua and also P. avium, which mainly occur in forest gaps or at forest margins.

\section{Tree ring analysis}

The dendrochronological analyses indicated relatively low age differences between the sampled individuals (table 4), ranging on average between 94 (A. campestre) and 121 years (Q. petraea), albeit with a high variability of individual tree age. F. sylvatica and S. torminalis sowed the highest $\left(2.21 \mathrm{~mm} \mathrm{a}^{-1}\right)$ and lowest $\left(1.27 \mathrm{~mm} \mathrm{a}^{-1}\right)$ mean yearly radial incre- 
Table 4 Dendrometrical and dendrochronological characteristics of the investigated tree species, assigned to the ecological groups as resulting from regional DCA ordination

\begin{tabular}{|c|c|c|c|c|c|c|c|c|c|c|}
\hline \multirow[t]{2}{*}{ Tree species } & \multicolumn{2}{|c|}{$\begin{array}{l}\text { Quercus } \\
\text { petraea }\end{array}$} & \multicolumn{2}{|c|}{$\begin{array}{l}\text { Fagus } \\
\text { sylvatica }\end{array}$} & \multicolumn{2}{|c|}{$\begin{array}{l}\text { Sorbus } \\
\text { torminalis }\end{array}$} & \multicolumn{2}{|c|}{$\begin{array}{l}\text { Acer } \\
\text { campestre }\end{array}$} & \multicolumn{2}{|c|}{$\begin{array}{l}\text { Acer } \\
\text { platanoides }\end{array}$} \\
\hline & value & $( \pm \mathrm{SD})$ & value & $( \pm \mathrm{SD})$ & value & $( \pm \mathrm{SD})$ & value & $( \pm \mathrm{SD})$ & value & $( \pm \mathrm{SD})$ \\
\hline Study sites $(N)$ & 11 & & 10 & & 2 & & 2 & & 1 & \\
\hline Measured trees $(N)$ & 132 & & 131 & & 17 & & 18 & & 9 & \\
\hline Age (mean) & 121 & $(35.88)$ & 95 & $(21.10)$ & 104 & $(22.32)$ & 94 & $(15.64)$ & 106 & $(4.72)$ \\
\hline Age min-max (yrs) & $68-214$ & & $43-153$ & & $80-171$ & & $62-120$ & & $100-115$ & \\
\hline $\begin{array}{l}\text { Radial increment } \\
(\mathrm{mm} / \mathrm{yr})\end{array}$ & 1.55 & $(0.31)$ & 2.21 & $(0.56)$ & 1.27 & $(0.33)$ & 1.60 & $(0.32)$ & 1.62 & $(0.17)$ \\
\hline $\begin{array}{l}\text { Expressed } \\
\text { population signal } \\
\text { (EPS) }\end{array}$ & 0.932 & $(0.03)$ & 0.865 & $(0.14)$ & 0.419 & $(0.31)$ & 0.664 & $(0.03$ & 0.433 & \\
\hline $\begin{array}{l}\text { Inter series } \\
\text { correlation (Rbar) }\end{array}$ & 0.532 & $(0.07)$ & 0.404 & $(0.18)$ & 0.120 & $(0.10)$ & 0.208 & $(0.02)$ & 0.084 & \\
\hline $\begin{array}{l}\text { Mean sensitivity } \\
\text { (MS) }\end{array}$ & 0.253 & $(0.02)$ & 0.295 & $(0.04)$ & 0.239 & $(0.05)$ & 0.413 & $(0.04)$ & 0.420 & \\
\hline
\end{tabular}

ments, respectively. The values for EPS, Rbar, and MS indicated a high interseries correlation and a strong common environmental forcing for $Q$. petraea and F. sylvatica, while the values for the minor broadleaf species suggested higher individual variability of the tree-ring data. However, sample size for these species was too low to produce reliable chronologies.

Growth response during the three examined drought years indicated only one significant increment decrease for $Q$. petraea in one site for the drought year 1976 (Supporting Information 3, table 9, DCA/ISA group I-II). The radial growth of $S$. torminalis (group I) declined only in the drought year 1976 in one site. Also, radial increment of S. torminalis and $Q$. petraea decreased only by about $15-20 \%$ in drought years (figure 6). While the radial growth of $A$. campestre (group I/III) was reduced by on average $35 \%$ in a drought year, thus occupying an intermediate position, A. platanoides and particularly $F$. sylvatica (both group II) displayed even greater growth depressions $(>40 \%$ ) compared to pre-drought years. Moreover, F. sylvatica showed significant drought-induced growth reductions in 70 $\%$ of the study sites in 1976 (Supporting Infor- mation 3, table 9).

After a drought event, radial growth of $F$. sylvatica and both Acer species recovered significantly faster than that of $S$. torminalis and $Q$. petraea (figure 6). Five years after a drought event, annual increment reached up to $160 \%$ of the pre-drought level in F. sylvatica; the two Acer species also showed considerable 'overshooting' of growth after drought events. Also in $Q$ petraea and $S$ torminalis, full recovery was recorded after five years, but no overshooting occurred.

\section{Discussion}

\section{Analysis methods}

The main aim of our study was to rate the currently most important tree species in a relatively warm and dry region of Central Europe with respect to their predicted future growth and survival chances under climate change. To not depend on one single method alone, we considered three methods commonly applied in forest ecological research: species distribution models (SDM), indicator species-based 

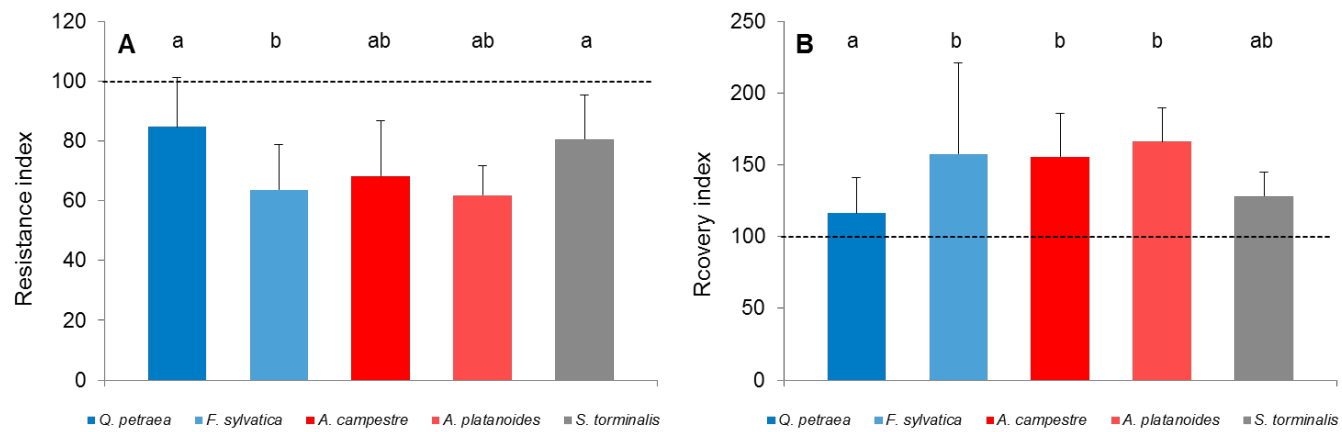

Figure 6 Mean relative radial increment of 5 tree species during (left, index of resistance) and after (right, index of recovery) drought years in 1947, 1976 and 2003 (see also Table 3 and Supporting Information 3, table 9). Increment values of $100 \%$ (dashed line) indicate no decline in growth during the drought year (left) or a complete increment recovery within a period of five years after the drought year (right). The standard deviation of the mean is indicated by whiskers, different letters indicate significant differences between the tree species (one-way ANOVA, $\mathrm{p}<0.05$ ).

ecological niches (DCA/ISA), and tree ring analyses (TRA). By comparing the outcomes of these approaches, we expected to obtain a more differentiated picture than any single method provides. Table 3 summarizes the results for the 18 tree species present in the SDM and DCA/ISA; five of them were sampled by means of TRA. Among the studied species are several less common species which are of interest to foresters to increase biodiversity and ecosystem resilience, but for which relatively little information exists in the literature.

The SDM results are based on species distributions on a European scale. They were kept very parsimonious in using three variables only. Mellert et al. (2015) showed for beech that the three variables we used act as proxies for the limitation due to cold and frost (BIO6) as well as for summer heat (BIO10) and drought (BIO18). High winter temperatures (proxy BIO6) may also limit some species with a need for dormancy. We assume that on a continental scale, these limits are the same for the other species in this study and that they are likely to be the main climatic constraints for the future suitability of the current species spectrum. Hence, the selected variables meet major hypotheses on distribution limits and physiological plausibility (Mellert et al. 2011). While in the case of SDMs, a parsimonious set of variables assures a higher generality (Sharpe 1990) and comparability between the species parameterisation, ISA (in conjunction with DCA and EIVs) provides a more detailed insight into the local niche divergence. At the local scale, topography, mesoclimate and soil are more important for species occurrences. TRA, finally, is able to trace tree species sensitivity to climatic extremes over a temporal record of several decades. SDMs can be improved by integrating soil factors or extreme events (Coudun et al. 2006, Zimmermann et al. 2009). Instead of trying to integrate soil factors and climate extremes with imprecise data on a continental scale into one SDM approach, we compare different drivers acting on different spatial and temporal scales that can give us hints on drought tolerance.

\section{Comparison of the different drought toler- ance rankings}

In general, the rating generated by species distribution modelling (SDM) matched reasonably well with the ecological niche analysis, and also with the dendroecological results on 
growth responses to drought (table 3). Also, the drought tolerance ranking of Niinemets \& Valladares (2006) agrees with the favorability of the 2061-2080 climate for individual tree species calculated by our models (Spearman rank correlation $r=0.45$, without Scots pine $r=0.66$ ). Many tree species that achieved medium to high favorability scores in the SDMs were grouped in the moderately xerotolerant group I (S. aria, S. torminalis, U. minor and T. platyphyllos) or group I - II (Q. petraea, C. betulus) by the ecological niche analysis. This grouping matches the dendroecological findings for $Q$. petraea and $S$. torminalis, which showed no or only small increment decline in drought years. The higher drought tolerance of oak species compared to e.g. beech has also been confirmed by several studies (e.g. Leuschner et al. 2001, Friedrichs et al. 2009, Michelot et al. 2012, Mette et al. 2013). There is still a lack of studies on the growth performance and drought sensitivity of minor Central European broadleaf tree species such Acer, Tilia, Carpinus and Sorbus species (Pyttel et al. 2013, Gillner et al. 2014). However, our results are in accordance with further dendroecological (Cedro \& Cedro 2015, Klemmt et al. 2015, Zimmermann et al. 2015, Cedro 2016), as well as physiological studies (Tissier et al. 2004, Nardini et al. 2012, Kunz et al. 2016) assessing the drought tolerance of minor tree species.

Figure 2 shows that many of the more drought-tolerant species already play a dominant role in the broadleaf stands of the Franconian Plateau according to the NFI, especially $Q$. petraea and C. betulus. A comparatively high drought tolerance of $A$. campestre was indicated by both the SDM and local tree species response (group I/III; bimodal distribution). The bimodality of $A$. campestre highlights the fact that the mean indicator values for temperature $(\mathrm{mT})$ and moisture $(\mathrm{mF})$ do not necessarily reflect the main distribution of the species, and should in some cases be interpreted with caution. The dendroecological results indicat- ed an intermediate response pattern between the moderately xerotolerant (S. torminalis, $Q$. petraea) and the mesophilous tree species $(A$. platanoides, F. sylvatica). Bartlett et al. (2012) rank three of our five key species in terms of drought tolerance according to their leaf water potential at turgor loss, or wilting, in increasing order: A. campestre, F. sylvatica, and $Q$. petraea. Their ranking of $A$. campestre differs from our findings, but as the authors note, leaf water potential should not be taken as the only factor to evaluate drought tolerance.

Species with low favorability of warmer and drier climates in the SDMs were mainly placed into the mesophilous group II by ecological niche analysis, e.g. F. sylvatica, A. platanoides and A. pseudoplatanus. A. platanoides in particular was shown by the SDM to reach an abrupt threshold with increasing temperature. The tree ring analysis of $F$. sylvatica and $A$. platanoides also revealed significantly stronger declines of radial increment than for $S$. torminalis and Q. petraea (groups I and I-II by ISA/DCA), while at the same time the recovery reaction was much stronger. The high mean sensitivity scores of $F$. sylvatica and $A$. platanoides may also indicate a higher sensitivity to inter-annual climatic variations.

At first sight, the drought categorizations in the case of $F$. excelsior and $Q$. robur seem to mismatch: both species can be interpreted as medium drought tolerant from the SDMs, but were found to be linked to moist soils (group III) in the fine-scale ecological niche analysis. As in the case of $A$. campestre, the assignment of $Q$. robur and $F$. excelsior to the moist soil group III does not necessarily make them vulnerable to high temperature and low precipitation. Based on their high vitality on clayey waterlogged bottomland soils, their tolerance of high water tables and hypoxia, and high regeneration capacity after damage (e.g. by late frost) they may profit from a cooler topoclimate and a more favorable nutrient and water supply on valley bottoms and depressions. Such specific information can only be includ- 
ed in species distribution models if data on soil properties are available (Coudun et al. 2006, Hiederer et al. 2011, Bertrand et al. 2012). However, it is crucial for assessing fitness for cultivation purposes of broadly sympatric species as in the case of Quercus (Van Valen 1976).

In the case of $T$. platyphyllos (group I) and T. cordata (group III), SDM and DCA both identified the current climate trend as being more favorable for T. platyphyllos. This is in contrast with Niinemets \& Valladares (2006) who rank $T$. cordata as being the more drought tolerant species. Fini et al. (2009) also ranked $T$. cordata as more drought tolerant during establishment phase in an urban forestry irrigation experiment. $T$. platyphyllos has the lowest prevalence in the SDM analysis, thus the model output should be interpreted with caution. Due to its subatlantic and sub-Mediterranean distribution (Bohn et al. 2000-2003) it has a higher demand for warm temperatures, which is reflected by the model output. As high temperatures are only tolerated with a certain amount of humidity (e.g. soil or air humidity; Mayer 1984), the SDM output does not reflect drought tolerance but temperature tolerance. The SDM for T. cordata reflects its more subcontinental distribution (Bohn et al. 20002003) with higher abundance in eastern Europe (e.g. Poland) and does not fully cover the warm and dry distribution edge, e.g. in France. The rise in winter temperatures decreases the favorability for the latter species because there are no presences in the training data with both dry conditions and mild winter. Certainly, also the suitability of the Tilia-species for cultivation purposes on a local level has to regard their partitioned ecological niches (sympatric speciation of closely related sister species).

Somewhat related to the situation with group III is the heliophilous group " $h$ ". This group consists of pioneer species like $P$. tremula, $L$. decidua and $B$. pendula, where the common denominator is the high Ellenberg light indicator value. The short-lived $P$. avium is shade tol- erant as a sapling (Ellenberg et al. 1992), but established trees are generally found in more open stands (Abs et al. 2008). Here, the indicator species analysis provides no information on drought susceptibility. These species (and also $P$. sylvestris [planted]) as elements of early-successional forest phases generally are considered as difficult to model with respect to their climate dependence (Guisan et al. 2007) and are ranked low in terms of favorability (see table 3) with the exception of $P$. avium.

Special attention must be paid to $P$. sylvestris, which is still the standard choice for forest development on sandy soils with poor water and nutrient retention capacities. Despite being considered as a drought-tolerant species in Central Europe (Niinemets \& Valladares 2006, Ellenberg \& Leuschner 2010), its current distribution in Europe seems to indicate that Scots pine is primarily a species sensitive to higher temperatures (Herrero et al. 2013, Rigling et al. 2013). Recent diebacks in the Nuremberg region following the 2015 summer drought and heat seem to confirm that Scots pine is not well adapted to high temperatures (pers. communication C. Kölling), which supports the results of our favorability analysis.

\section{Tree ring analysis and vulnerability to drought}

Arguably, the diameter increment reaction in drought years may not unambiguously indicate a species' vulnerability to drought (Breda et al. 2006, McDowell et al. 2008, Lloret et al. 2011, Pretzsch et al. 2013). In our case, for instance, even the more drought-sensitive beech and maple recovered to the pre-drought increment level or even overshot (Pretzsch et al. 2013, Zimmermann et al. 2015). Also, only few studies have shown that higher ring width variability, i.e. the mean sensitivity, is linked to a higher mortality during extreme drought (Ogle et al. 2000). From our study, comparison with the other methods shows that the strongest drought-induced decreases in ring width 
occurred in species with a lower abundance in drier regions, suggesting that their reactions to drought may have an influence on longterm fitness. Beside growth sensitivity, wood anatomical traits (e.g., Eilmann et al. 2014, Schuldt et al. 2015) and physiological parameters expressing plant survival under drought (e.g. Bolte et al. 2016) may provide better estimates of lethal effects of drought on tree species than radial growth alone. They therefore may be useful additional information to be combined with SDMs.

\section{Conclusions}

Most current recommendations for forest stand management under future climate conditions are based on predictions of species responses derived purely from species distribution models. SDMs are regression- or data mining-based techniques and therefore are correlative approaches that lack ecophysiological explanation, but produce useful hypotheses regarding species traits. By combining the results of SDMs with ecological niche analysis and tree ring analysis in this study, we provide a more differentiated picture of the future suitability of tree species in the warm dry region of the Franconian Plateau in southern Germany. Our results show that the oak and beech forests that currently dominate in the area are not yet at their climatic limit. Especially Q. petraea can persist under elevated temperatures, whilst for F. sylvatica, it appears that temperature rise must be compensated by considerable increases in summer precipitation to maintain vitality. Our results match with those of Mette et al. (2013), who concluded that F. sylvatica is currently not critically growth-limited by drought in this region. However, beech has been suffering from long-term radial growth decline since about the 1980s in various regions of Central Europe at lower elevations (e.g. Scharnweber et al. 2011, Kint et al. 2012, Zimmermann et al. 2015), which suggests that Fagus is relatively sensitive to a warmer and drier climate. Where clayey and moist soils provide sufficient nutrient and water supply, species like $Q$. robur and F. excelsior can potentially survive further temperature increases. Besides these two species, we also analyzed several less common species, of which Acer campestre, Sorbus torminalis, Sorbus aria and Ulmus minor appeared as suitable drought tolerant species. Especially for these species where data are rare, it is useful to crosscheck results from other methods. In general, the assessment of the future suitability of tree species by a mix of different approaches is a valuable means to reduce uncertainties due to the unavoidable limitations of individual methods. This is especially important for the long-term decisions necessary to adapt the species spectrum of a forest stand in anticipation of expected climate change.

\section{Acknowledgments}

Jörg Kunz received a $\mathrm{PhD}$ scholarship of the Landesgraduiertenförderung Baden-Württemberg (LGFG) and further support through the Graduate School 'Environment, Society and Global Change' at the Albert-Ludwigs-University Freiburg as well as grants by the Georg-Ludwig-Hartig Foundation. Cathrin Meinardus was supported by the Bavarian Research Cooperation "Climatic Impacts on Ecosystems and Climatic Adaption Strategies" (FORKAST) funded by the Bavarian State Ministry of Sciences, Research and the Arts.

We thank our colleagues from the Bavarian State Institute of Forestry, namely Dr. Thomas Kudernatsch for his insightful comments on our manuscript and Stefan Schuster for creating the survey map. Dr. Lothar Zimmermann helped obtaining climate data. Hans Stark, head of the University forestry office of Sailershausen, supported us by technical information and indications and rendered organizational assistance in the field. 


\section{References}

Abs C., Ewald J., Walentowski H., Winter S., 2008. Untersuchung der Schattentoleranz von Baumarten auf Grundlage der Datenbank bayerischer Naturwaldreservate [Shade tolerance of tree species - an analysis based on the databank of Bavarian natural forest reserves]. Tuexenia 28: 23-40.

Austin M.P., Gaywood M.J., 1994. Current problems of environmental gradients and species response curves in relation to continuum theory. Journal of Vegetation Science 5: 473-482. DOI: 10.2307/3235973

Austin M.P., Van Niel K.P., 2011. Improving species distribution models for climate change studies: variable selection and scale. Journal of Biogeography 38: 1-8. DOI: $10.1111 /$ j.1365-2699.2010.02416.x

Bahn M., Reichstein M., Guan K., Moreno J.M., Williams C., 2015. Preface: Climate extremes and biogeochemical cycles in the terrestrial biosphere: impacts and feedbacks across scales. Biogeosciences 12: 4827-4830. DOI: $10.5194 /$ bg-12-4827-2015

Bartlett M.K., Scoffoni C., Sack L., 2012. The determinants of leaf turgor loss point and prediction of drought tolerance of species and biomes: a global meta-analysis. Ecology Letters, 15: 393-405. DOI: 10.1111/j.14610248.2012.01751.x

Bertrand R., Perez V., Gégout J.C., 2012. Disregarding the edaphic dimension in species distribution models leads to the omission of crucial spatial information under climate change: the case of Quercus pubescens in France. Global Change Biology 18: 2648-2660. DOI: 10.1111/j.1365-2486.2012.02679.x

Bigler C., Bugmann H., 2003. Growth-dependent tree mortality models based on tree rings. Canadian Journal of Forest Research 33: 210-221. DOI: 10.1139/x02-180

Bohn U., Neuhäusl R., Gollub G., Hettwer C., Neuhäuslová Z., Schlüter H., Weber H (ed.), 2000-2003. Karte der natürlichen Vegetation Europas. Maßstab 1:2,500,000. Teil 1-3 [Map of the Natural Vegetation of Europe. Scale 1: 2.5 million. Part 1-3]. Landwirtschaftsverlag, Münster, $655 \mathrm{p}$.

Bolte A., Czajkowski T., Kompa T., 2007. The north-eastern distribution range of European beech - a review. Forestry 80: 413-429. DOI: 10.1093/forestry/cpm028

Bolte A., Czajkowski T., Cocozza C., Tognetti R., de Miguel M., Pšidová E., Ditmarová Ĺ., Dinca L., Delzon S., Cochard H., Ræbild A., de Luis M., Cvjetkovic B., Heiri C., Müller J., 2016. Desiccation and mortality dynamics in seedlings of different European beech (Fagus sylvatica L.) populations under extreme drought conditions. Frontiers in Plant Science 7: 751. DOI: 10.3389/ fpls.2016.00751

Bouriaud O., Popa I., 2009. Comparative dendroclimatic study of Scots pine, Norway spruce, and silver fir in the Vrancea Range, Eastern Carpathian Mountains. Trees 23: 95-106. DOI: 10.1007/s00468-008-0258-z

Brang P., Bugmann H., Bürgi A., Mühlethaler U., Rigling
A., Schwitter R., 2008. Klimawandel als waldbauliche Herausforderung [Climate change as a challenge for silviculture.]. Schweizerische Zeitschrift für Forstwesen 159: 362-373. DOI: $10.3188 /$ szf.2008.0362

Bréda N., Huc R., Granier A., Dreyer E., 2006. Temperate forest trees and stands under severe drought: A review of ecophysiological responses, adaption processes and long-term consequences. Annals of Forest Science 63: 625-644. DOI: 10.1051/forest:2006042

Bunn A.G., 2008. A dendrochronology program library in $\mathrm{R}$ (dplR). Dendrochronologia 26: 115-124. DOI: 10.1016/j.dendro.2008.01.002

Cavin L., Mountford E.P., Peterken G.F., Jump A.S., 2013. Extreme drought alters competitive dominance within and between tree species in a mixed forest stand. Functional Ecology 27: 1424-1435. DOI: 10.1111/13652435.12126

Cedro A., Cedro B., 2015. Growth-climate relationships at yew and wild service trees on the eastern edge of their range in Europe. Forest Systems 24: e044. DOI: $10.5424 /$ fs $/ 2015243-07480$

Cedro A., 2016. The influence of climatic conditions on the tree-ring width of wild service trees (Sorbus torminalis L.) in Wielkopolska. Forest Research Papers 77: 117-123. DOI: 10.1515/frp-2016-0013

Chakraborty D., Wang T., Andre K., Konnert M., Lexer M.J., Matulla C., Schueler S., 2015. Selecting populations for non-analogous climate conditions using Universal Response Functions: The Case of Douglas-Fir in Central Europe. PloS one 10: e0136357. DOI: 10.1371/ journal.pone. 0136357

Ciais P., Reichstein M., Viovy N., Granier A., Ogée J., Allard V., Aubinet M., Buchmann N., Bernhofer C., Carrara A., Chevallier F., De Noblet N., Friend A.D., Friedlingstein P., Grünwald T., Heinesch B., Keronen P., Knohl A., Krinner G., Loustau D., Manca G., Matteucci G., Miglietta F., Ourcival J.M., Papale D., Pilegaard K., Rambal S., Seufert G., Soussana J.F., Sanz M.J., Schulze E.D., Vesala T., Valentini R., 2005. Europe-wide reduction in primary productivity caused by the heat and drought in 2003. Nature 437: 529-533. DOI: 10.1038 /nature03972

Cook E.R., 1987. The decomposition of tree-ring series for environmental studies. Tree-Ring Bulletin 47: 37-59.

Cook E.R., Briffa K.R., Shiyatov S., Mazepa A., Jones P.D., 1990. Data analysis. In Cook, E.R., Kairiukstis, L.A. (ed.), Methods of dendrochronology: Applications in the environmental sciences. Kluwer Academic Publishers, Dodrecht, pp. 97-162. DOI: 10.1007/978-94015-7879-0_3

Cook E.R., Peters K., 1997. Calculating unbiased treering indices for the study of climatic and environmental change. The Holocene 7: 361-370. DOI: 10.1177/095968369700700314

Coudun C., Gégout J.C., Piedallu C., Rameau J.C., 2006. Soil nutritional factors improve models of plant species distribution: an illustration with Acer campestre (L.) in France. Journal of Biogeography 33: 1750-1763. DOI: 
10.1111/j.1365-2699.2005.01443.x

Coumou D., Rahmstorf S., 2012. A decade of weather extremes. Nature Climate Change 2: 491-496. DOI: 10.1038/nclimate 1452

Dierschke H., 1994. Pflanzensoziologie - Grundlagen und Methoden [Phytosociology - foundations and methods]. Ulmer, Suttgart, 683 p.

Dittmar C., Lieber K.-H., Rothe A., Zang C., 2012. Tanne im Weinbauklima. AFZ-DerWald 67: 4-7.

Dittmar C., Zech W., Elling W., 2003. Growth variations of Common beech (Fagus sylvatica L.) under different climatic and environmental conditions in Europe - a dendroecological study. Forest Ecology and Management 173: 63-78. DOI: 10.1016/S0378-1127(01)008167

Dufrêne M., Legendre P., 1997. Species assemblages and indicator species: the need for a flexible asymmetrical approach. Ecological Monographs 67: 345-366. DOI: $10.2307 / 2963459$

Eilmann B., Weber P., Rigling A., Eckstein D. 2006. Growth reactions of Pinus sylvestris L. and Quercus pubescens Willd. to drought years at a xeric site in Valais, Switzerland. Dendrochronologia 23: 121-132. DOI: 10.1016/j.dendro.2005.10.002

Eilmann B., Sterck F., Wegner L., de Vries S.M., von Arx G., Mohren G.M., den Ouden J., Sass-Klaassen U., 2014. Wood structural differences between northern and southern beech provenances growing at a moderate site. Tree Physiology 34: 882-893. DOI: 10.1093/ treephys/tpu069

Elith J., Leathwick J.R., Hastie T., 2008. A working guide to boosted regression trees. Journal of Animal Ecology 77: 802-813. DOI: 10.1111/j.1365-2656.2008.01390.x

Ellenberg H., Leuschner C., 2010. Vegetation Mitteleuropas mit den Alpen. 6th ed., Ulmer, Stuttgart, 1333 p.

Ellenberg H., Weber H.E., Düll R., Wirth V., Werner W., 2001. Zeigerwerte von Pflanzen in Mitteleuropa. Scripta Geobotanica 18: 1-262.

European Commission, 2000. EUR 19550 - COST Action E4 - Forest reserves research network. Office for Official Publications of the European Communities, Luxembourg, $377 \mathrm{p}$.

Ewald J., 2007. Beurteilung von Waldstandorten und Waldgesellschaften mit Zeigerarten-Ökogrammen. Tuexenia 27: 7-18.

Falk W., Hempelmann, N., 2013. Species Favourability Shift in Europe due to climate change: A case study for Fagus sylvatica L. and Picea abies (L.) Karst. based on an ensemble of climate models. Journal of Climatology 2013: Article ID 787250. DOI: $10.1155 / 2013 / 787250$

Falk W., Mellert K.H., 2011. Species distribution models as a tool for forest management planning under climate change: risk evaluation of Abies alba in Bavaria. Journal of Vegetation Science 22: 621-634. DOI: 10.1111/j.1654-1103.2011.01294.x

Fanelli G., Pignatti S., Testi A., 2007. An application case of ecological indicator values (Zeigerwerte) calculated with a simple algorithmic approach. Plant Biosystems
141: 15-21. DOI: 10.1080/11263500601153685

Fensham R.J., Bouchard D.L., Catterall C.P., Dwyer, J.M., 2014. Do local moisture stress responses across tree species reflect dry limits of their geographic ranges? Austral Ecology 39: 612-618. DOI: 10.1111/aec.12125

Fini A., Ferrini F., Frangi P., Amoroso G., Piatti R., 2009. Withholding irrigation during the establishment phase affected growth and physiology of Norway Maple (Acer platanoides) and Linden (Tilia spp.). Arboriculture \& Urban Forestry 35: 241-251.

Franklin J., 2010. Mapping species distributions: spatial inference and prediction. Cambridge University Press, Cambridge, 320 p. DOI: 10.1017/CBO9780511810602

Freeman E.A., Moisen G.G., 2008a PresenceAbsence: an $\mathrm{R}$ package for PresenceAbsence analysis. Journal of Statistical Software 23: 1-31. DOI: 10.18637/jss.v023. i11

Freeman E.A., Moisen G.G., 2008b. A comparison of the performance of threshold criteria for binary classification in terms of predicted prevalence and kappa. Ecological Modelling 217: 48-58. DOI: 10.1016/j.ecolmodel.2008.05.015

Friedrichs D.A., Trouet V., Büntgen U., Frank D.C., Esper J., Neuwirth B., Löffler J., 2009. Species-specific climate sensitivity of tree growth in Central-West Germany. Trees 23: 729-739. DOI: 10.1007/s00468-0090315-2

Fritts H.C., 1976. Tree Rings and Climate. Academic Press, London, $567 \mathrm{p}$.

Gillner S., Bräuning A., Roloff A., 2014. Dendrochronological analysis of urban trees: climatic response and impact of drought on frequently used tree species. Trees 28: 1079-1093. DOI: 10.1007/s00468-014-1019-9

Guisan A., Zimmermann N.E., Elith J., Graham C.H., Phillips S., Peterson A.T., 2007. What matters for predicting the occurrences of trees: techniques, data, or species' characteristics? Ecological Monographs 77: 615-630. DOI: 10.1890/06-1060.1

Härdtle W., Ewald J., Hölzel N., 2004. Wälder des Tieflandes und der Mittelgebirge. Ulmer, Stuttgart, 252 p.

Hanewinkel M., Cullmann D.A., Michiels H.G., Kändler G., 2014. Converting probabilistic tree species range shift projections into meaningful classes for management. Journal of Environmental Management 134: 153165. DOI: 10.1016/j.jenvman.2014.01.010

Hanewinkel M., Cullmann D.A., Schelhaas M.J., Nabuurs G.J., Zimmermann N.E., 2013. Climate change may cause severe loss in the economic value of European forest land. Nature Climate Change 3: 203-207. DOI: $10.1038 /$ nclimate 1687

Hemery G.E., 2008. Forest management and silvicultural responses to projected climate change impacts on European broadleaved trees and forests. International Forestry Review 10: 591-607. DOI: 10.1505/ifor.10.4.591

Herrero A., Rigling A., Zamora R., 2013. Climate-tree growth analysis at the drought-linked distribution edge of Pinus sylvestris and Pinus nigra. Forest Ecology and Management 308: 50-61. DOI: 10.1016/j.fore- 
co.2013.07.034

Hiederer R., Michéli E., Durrant T., 2011. Evaluation of BioSoil. Demonstration Project. Soil Data Analysis. Publications Office of the European Union, Luxembourg, $155 \mathrm{p}$.

Hijmans R.J., Cameron S.E., Parra J.L., Jones P.G., Jarvis A., 2005. Very high resolution interpolated climate surfaces for global land areas. International Journal of Climatology 25: 1965-1978. DOI: 10.1002/joc.1276

Hill M.O., Gauch H.G., 1980. Detrended Correspondence Analysis: an improved ordination technique. Vegetatio 42: 47-58. DOI: 10.1007/BF00048870

Hirzel A.H., Le Lay G., 2008. Habitat suitability modelling and niche theory. Journal of Applied Ecology 45: 1372-1381. DOI: 10.1111/j.1365-2664.2008.01524.x

Hofmann W., 1964-65. Laubwaldgesellschaften der Fränkischen Platte - Eine vegetationskundliche, pflanzengeografische und bodenkundliche Untersuchung [Deciduous forest communities of the Franconian Plateau - A geobotanical, phytogeographical and pedological study]. Abhandlungen des Naturwissenschaftlichen Vereins Würzburg 5/6: 1-195.

IPCC, 2013. Impacts, Adaptation and Vulnerability. Contribution of Working Group II to the Fifth Assessment Report of the Intergovernmental Panel on Climate Change. Cambridge University Press, Cambridge, 1535 p.

Jahn G., 1991. Temperate deciduous forests of Europe. In Röhrig E., Ulrich B., (ed.). Temperate deciduous forests. Ecosystems of the world. Elsevier, Amsterdam, pp. 377-502.

Kint V., Aertsen W., Campioli M., Vansteenkiste D., Delcloo A., Muys B., 2012. Radial growth change of temperate tree species in response to altered regional climate and air quality in the period 1901-2008. Climatic Change 115: 343-363. DOI: 10.1007/s10584-0120465-X

Klemmt H.-J., Reger B., Falk W., Kunz J., 2015. Der Feldahorn - Vorkommen und Wachstum in Bayern [Field maple - occurrence and growth in Bavaria]. LWF Wissen 77: 30-39.

Kölling C., 2007. Klimahüllen für 27 Waldbaumarten [Bioclimate envelopes of 27 tree species]. AFZ-DerWald 62: 1242-1245.

Kunz J., Pyttel P., Grüner J., Bauhus J., 2011. Rindenschäden und Holzfäuleerreger an Elsbeere [Bark injuries and wood-rot pathogens on wild service tree]. AFZ-DerWald 66: 14-17.

Kunz J., Räder A., Bauhus J., 2016. Effects of drought and rewetting on growth and gas exchange of minor European broadleaved tree species. Forests 7: 239. DOI: 10.3390/f7100239

Leuschner C., Backes K., Hertel D., Schipka F., Schmitt U., Terborg O., Runge M., 2001. Drought responses at leaf, stem and fine root levels of competitive Fagus sylvatica L. and Quercus petraea (Matt.) Liebl. trees in dry and wet years. Forest Ecology and Management 149: 33-46. DOI: 10.1016/S0378-1127(00)00543-0
Lindner M., Maroschek M., Netherer S., Kremer A., Barbati A., Garcia-Gonzalo J., Seidl R., Delzon S., Corona P., Kolström M., Lexer M.J., Marchetti M., 2010. Climate change impacts, adaptive capacity, and vulnerability of European forest ecosystems. Forest Ecology and Management 259: 698-709. DOI: 10.1016/j.foreco.2009.09.023

Lindner, M., Fitzgerald, J. B., Zimmermann, N. E., Reyer, C., Delzon, S., van der Maaten, E., Schelhaas, M.J., Lasch, P., Eggers, J., van der Maaten-Theunissen, M., Suckow, F., Psomas, A., Poulter, B., Hanewinkel, M., 2014. Climate change and European forests: What do we know, what are the uncertainties, and what are the implications for forest management? Journal of Environmental Management 146: 69-83. DOI: 10.1016/j. jenvman.2014.07.030

Lloret F., Keeling E.G., Sala A., 2011. Components of tree resilience: effects of successive low-growth episodes in old ponderosa pine forests. Oikos 120: 1909-1920. DOI: $10.1111 / \mathrm{j} .1600-0706.2011 .19372 . \mathrm{x}$

Lorenz M., 1995. International co-operative programme on assessment and monitoring of air pollution effects on forests - ICP forests. Water, Air, \& Soil Pollution 85: 1221-1226. DOI: $10.1007 / \mathrm{BF} 00477148$

Mátyás C., Nagy L., Jármay E.U., 2009. Genetic background of response of trees to aridification at the xeric forest limit and con-sequences for bioclimatic modelling. In Strelcová K., Mátyás C., Kleidon A., Lapin M., Matejka F., Blazenec M., Škvarenina J., Holecy J. (ed.), Bioclimatology and natural hazards. Springer, Berlin, pp. 179-196. DOI: 10.1007/978-1-4020-8876-6_16

Mayer H., 1984. Waldbau auf soziologisch-ökologischer Grundlage [Silviculture on phytosociological-ecological foundation]. 3rd edn., Fischer, Stuttgart, 513 p.

McCune B., Grace J.B., 2002. Analysis of ecological communities. MjM Software Design, Gleneden Beach, 300 p.

McDowell N., Pockman W.T., Allen C.D., Breshears D.D., Cobb N., Kolb T., Plaut J., Sperry J., West A., Williams D.G., Yepez E.A., 2008. Mechanisms of plant survival and mortality during drought: Why do some plants survive while others succumb to drought? New Phytologist 178: 719-739. DOI: 10.1111/j.1469-8137.2008.02436.x Meinardus C., Bräuning A., 2011. Zur Trockenstresstoleranz von Eichen und Buchen [On drought resistance of oak and beech]. LWF aktuell 85: 9-11.

Mellert K.H., Deffner V., Küchenhoff H., Kölling C., 2015. Modeling sensitivity to climate change and estimating the uncertainty of its impact: a probabilistic concept for risk assessment in forestry. Ecological Modelling 316: 211-216. DOI: 10.1016/j.ecolmodel.2015.08.014

Mellert K.H., Fensterer V., Küchenhoff H., Reger B., Kölling C., Klemmt H.J., Ewald J., 2011. Hypothesis-driven species distribution models for tree species in the Bavarian Alps. Journal of Vegetation Science 22: 635-646. DOI: 10.1111/j.1654-1103.2011.01274.x

Melman T.C.P., Clausman P.H.M.A., de Haes U.H.A., 1988. The testing of three indicator systems for trophic 
state in grasslands. Vegetatio 75: 143-152.

Mette T, Dolos K., Meinardus C., Bräuning A., Reineking B., Blaschke M., Pretzsch H., Beierkuhnlein C., Gohlke A., Wellstein C., 2013. Climatic turning point for beech and oak under climate change in Central Europe. Ecosphere 4: 145. DOI: 10.1890/ES13-00115.1

Mette T., Falk W., Uhl E., Biber P., Pretzsch H., 2015. Increment allocation along the stem axis of dominant and suppressed trees in reaction to drought - results from 123 stem analyses of Norway spruce, Scots pine and European beech. Austrian Journal of Forest Science 132: 223-238.

Michelot A., Bréda N., Damesin C., Dufrêne E., 2012. Differing growth responses to climatic variations and soil water deficits of Fagus sylvatica, Quercus petraea and Pinus sylvestris in a temperate forest. Forest Ecology and Management 265: 161-171. DOI: 10.1016/j.foreco.2011.10.024

Nardini A., Dimasi F., Klepsch M., Jansen, S., 2012. Ion-mediated enhancement of xylem hydraulic conductivity in four Acer spe-cies: relationships with ecological and anatomical features. Tree Physiology 32: 14341441. DOI: $10.1093 /$ treephys/tps 107

Niinemets Ü., Valladares F., 2006. Tolerance to shade, drought, and waterlogging of temperate northern hemisphere trees and shrubs. Ecological Monographs 76: 521-547. DOI: 10.1890/0012-9615(2006)076[0521:TTSDAW]2.0.CO;2

Oberdorfer E. (ed.), 1992. Süddeutsche Pflanzengesellschaften, Teil 4: Wälder und Gebüsche [Plant communities of South Germany. Volume IV forests and shrubs]. 2nd edn., Fischer, Jena, 862 p.

Ogle K., Whitham T.G., Cobb N.S., 2000. Tree-ring variation in pinyon predicts likelihood of death following severe drought. Ecology 81: 3237-3243. DOI: 10.1890/0012-9658(2000)081[3237:TRVIPP]2.0.CO;2

Okland R.H., 1996. Are ordination and constrained ordination alternative or complementary strategies in general ecological studies. Journal of Vegetation Science 7: 289-292. DOI: $10.2307 / 3236330$

Pearson R.G., Dawson T.P., 2003. Predicting the impact of climate change and the distribution of species: are bioclimate envelope models useful? Global Ecology and Biogeography 12: 361-371. DOI: 10.1046/j.1466822X.2003.00042.x

Peck J.E., 2010. Multivariate analysis for community ecologists: Step-by-Step using PC-ORD. MjM Software Design, Gleneden Beach, $162 \mathrm{p}$.

Peterson A.T., Soberón J., Pearson R.G., Anderson R.P., Martínez-Meyer E., Nakamura M., Araújo M.B., 2011. Ecological niches and geographic distributions. Princeton University Press, Princeton, 314 p.

Piedallu C., Gégout J.-C., Perez V., Lebourgeois F., 2013. Soil water balance performs better than climatic water variables in tree spe-cies distribution modelling. Global Ecology and Biogeography 22: 470-482. DOI: 10.1111/ geb. 12012

Polley H., Schmitz F., Hennig P., Kroiher F., 2010. Nation- al forest inventories: chapter 13, Germany. In Tomppo E., Gschwantner T., Lawrence M., McRoberts R.E. (ed.), National Forest Inventories - pathways for common reporting. Springer, New York, pp. 223-243.

Pretzsch H., Schütze G., Uhl E., 2013. Resistance of European tree species to drought stress in mixed versus pure forests: evidence of stress release by inter-specific facilitation. Plant Biology 15: 483-495. DOI: 10.1111/j.1438-8677.2012.00670.x

Pudlatz H., 1975. Zur Transformation der Variablen bei mangelnder Normalverteilung [Transforming a non-normal distribution into a normal distribution]. Gießener Geographische Schriften 32: 29-33.

Pyttel P., Kunz J., Bauhus J., 2013. Growth, regeneration and shade tolerance of the Wild Service Tree (Sorbus torminalis (L.) Crantz) in aged oak coppice forests. Trees 27: 1609-1619. DOI: 10.1007/s00468-013-09087

Quiring S.M., 2009. Monitoring drought: an evaluation of meteorological drought indices. Geography Compass 3: 64-88. DOI: 10.1111/j.1749-8198.2008.00207.x

Real R., Barbosa A.M., Vargas J.M., 2006. Obtaining environmental favourability functions from logistic regression. Environmental and Ecological Statistics 13: 237-245. DOI: 10.1007/s10651-005-0003-3

Rigling A., Bigler C., Eilmann B., Mayer P., Ginzler C., Vacchiano G., Weber P., Wohlgemuth T., Zweifel R., Dobbertin M., 2013. Driving factors of a vegetation shift from Scots pine to pubescent oak in dry Alpine forests. Global Change Biology 19: 229-240. DOI: 10.1111/gcb. 12038

Schaffers A.P., Sýkora K.V., 2000. Reliability of Ellenberg indicator values for moisture, nitrogen and soil reaction: a comparison with field measurements. Journal of Vegetation Science 11: 225-244. DOI: 10.2307/3236802

Scharnweber T.M., Manthey M., Criegee C., Bauwe A., Schröder C., Wilmking M., 2011. Drought matters: Declining precipitation influences growth of Fagus sylvatica L. and Quercus robur L. in northeastern Germany. Forest Ecology and Management 262: 947-961. DOI: 10.1016/j.foreco.2011.05.026

Schmidtlein S., Ewald J., 2003. Landscape patterns of indicator plants for soil acidity in the Bavarian Alps. Journal of Biogeography 30: 1493-1503. DOI: 10.1046/j.1365-2699.2003.00879.x

Schrötter H., 2001. Vogelkirsche, Spitzahorn und Elsbeere: Drei wertvolle Baumarten in Mecklenburg-Vorpommern im Abseits [Wild cherry, Norway maple and wild service tree: Three valuable tree species in Mecklenburg-Western Pomerania, that standing aside]. Forst und Holz 56:188-196.

Schueler S., Falk W., Koskela J., Lefèvre F., Bozzano M., Hubert J., Kraigher H., Longauer R., Olrik D.C., 2014. Vulnerability of dynamic genetic conservation units of forest trees in Europe to climate change. Global Change Biology 20: 1498-1511. DOI: 10.1111/gcb.12476

Schuldt B., Knutzen F., Delzon S., Jansen S., Müller-Haubold H., Burlett R., Clough Y., Leuschner C., 2016. 
How adaptable is the hydraulic system of European beech in the face of climate change-related precipitation reduction? New Phytologist 210: 443-458. DOI: 10.1111/nph.13798

Schweingruber F.H., 1988. Tree rings. Basics and applications of dendrochronology. Reidel, Dordrecht, $276 \mathrm{p}$.

Seneviratne, S.I., Nicholls N., Easterling D., Goodess C.M., Kanae S., Kossin J., Luo Y., Marengo J., McInnes K., Rahimi M., Reichstein M., Sorteberg A., Vera C., Zhang X., 2012. Changes in climate extremes and their impacts on the natural physical envi-ronment. In Field C.B., Barros V., Stocker T.F., Qin D., Dokken D.J., Ebi K.L., Mastrandrea M.D., Mach K.J., Plattner G.-K., Allen S.K., Tignor M.Midgley P.M. (eds.). Managing the risks of extreme events and disasters to advance climate change adaptation (IPCC SREX Report). Cambridge University Press, Cambridge, pp.109-230.

Sharpe P.J., 1990. Forest modeling approaches: compromises between generality and precision. In Dixon R.K. (ed.). Process modeling of forest growth responses to environmental stress. Timber Press, Portland, pp. 180190.

Taeger S., Kölling C., 2016. Standortinformationssystem BaSIS [Forest site mapping classification system BaSIS]. AFZ-DerWald 71: 10-13.

Thuiller W., Lafourcade B., Engler R., Araújo M.B., 2009. BIOMOD - a platform for ensemble forecasting of species distributions. Ecography 32: 369-373. DOI: 10.1111/j.1600-0587.2008.05742.x

Tissier J., Lambs L., Peltier J.P., Marigo G., 2004. Relationships between hydraulic traits and habitat preference for six Acer species occurring in the French Alps. Annals of Forest Science 61: 81-86. DOI: 10.1051/forest:2003087

Trenberth K.E., 2010. Changes in precipitation with climate change. Climate Research 47: 123-138. DOI: $10.3354 / \mathrm{cr} 00953$

Van Valen L., 1976. Ecological species, multispecies, and oaks. Taxon 25: 233-239. DOI: 10.2307/1219444

Vicente-Serrano S.M., Beguería S., López-Moreno J.I., 2010. A multiscalar drought index sensitive to global warming: The Standard-ized Precipitation Evapotranspiration Index. Journal of Climate 23: 1696-1718. DOI: 10.1175/2009JCLI2909.1

Walentowski H., Ewald J., Fischer A., Kölling C., Türk W. 2013. Handbuch der natürlichen Waldgesellschaften Bayerns [Handbook of Bavarian forest communities]. 3rd edn, Geobotanica, Freising, 441 p.

Walentowski H., Kudernatsch T., Fischer A., Ewald J., 2014. Naturwaldreservatsforschung in Bayern - Auswertung von Vegeta-tionsdaten zur waldökologischen Dauerbeobachtung [Strict forest nature reserves research in Bavaria - analysis of vegetation data for ecological long-term observation]. Tuexenia 34: 89-106.

Ward J.H., 1963. Hierarchical grouping to optimize an objective function. Journal of the American Statistical Association 58: 236-244. DOI: 10.1080/01621459.1963.10500845
Weber E., 2003. Invasive plant species of the world. A reference guide to environmental weeds. CABI Publishing, Wallingford, $548 \mathrm{p}$.

Weber P., Bugmann H., Pluess A.R., Walthert L., Rigling A., 2013. Drought response and changing mean sensitivity of European beech close to the dry distribution limit. Trees 27: 171-181. DOI: 10.1007/s00468-0120786-4

Wigley T.M.L., Briffa K.R., Jones P.D., 1984. On the average value of correlated time series, with applications in dendroclimatology and hydrometeorology. Journal of Climate and Applied Meteorology 23: 201-213. DOI: 10.1175/1520-0450(1984)023<0201:OTAVOC $>2.0$. $\mathrm{CO} ; 2$

Williams A.P., Allen C.D., Macalady A.K., Griffin D., Woodhouse C.A., Meko D.M., Swetnam T.S., Rauscher S.A., Seager R., Grissino-Mayer H.D., Dean J.S., Cook E.R., Gangodagamage C., Cai M., McDowell N.G., 2013. Temperature as a potent driver of region-al forest drought stress and tree mortality. Nature Climate Change 3: 292-297. DOI: 10.1038/nclimate1693

Wood S.N., 2006. Generalized Additive Models: An introduction with R. Chapman \& Hall / CRC, Boca Raton, $410 \mathrm{p}$.

Wood S.N., 2011. Fast stable restricted maximum likelihood and marginal likelihood estimation of semiparametric generalized linear models. Journal of the Royal Statistical Society (B) 7: 3-36. DOI: 10.1111/j.14679868.2010.00749.x

Wood S.N., Augustin N.H., 2002. GAMs with integrated model selection using penalized regression splines and applications to environmental modelling. Ecological Modelling 157: 157-177. DOI: 10.1016/S03043800(02)00193-X

Xu T., Hutchinson M.F., 2011. ANUCLIM VERSION 6.1 User's Guide. Fenner School of Environment and Society. The Australian National University. Web: http:// fennerschool.anu.edu.au/files/anuclim61.pdf. Accessed 13 March 2017.

Zelený D., Schaffers A.P., 2012. Too good to be true: pitfalls of using mean Ellenberg indicator values in vegetation analyses. Journal of Vegetation Science 23: 419431. DOI: 10.1111/j.1654-1103.2011.01366.x

Zang C., Hartl-Meier C., Dittmar C., Rothe A., Menzel A., 2014. Patterns of drought tolerance in major European temperate forest trees: climatic drivers and levels of variability. Global Change Biology 20: 3767-3779. DOI: $10.1111 / \mathrm{gcb} .12637$

Zang C., Rothe A., Weis W., Pretzsch H., 2011. Zur Baumarteneignung bei Klimawandel: Ableitung der Trockenstressanfälligkeit wichtiger Waldbaumarten aus Jahrringbreiten [Tree suitability under climate change conditions: susceptibility of major forest tree species from tree-rings widths]. Allgemeine Forst- und Jagdzeitung 182: 98-112.

Zimmermann J., Hauck M., Dulamsuren C., Leuschner C., 2015. Climate warming-related growth decline affects Fagus sylvatica, but not other broad-leaved tree species 
in Central European mixed forests. Ecosystems 18: 560-572. DOI: 10.1007/s10021-015-9849-X

Zimmermann N.E., Yoccoz N.G., Edwards Jr. T.C., Meier E.S., Thuiller W., Guisan A., Schmatz D.R., Pearman P.B., 2009. Climatic extremes improve predictions of spatial patterns of tree species. PNAS 106:1972319728. DOI: 10.1073/pnas.0901643106

Zimmermann N.E., Edwards T.C., Graham C.H., Pearman P.B., Svenning J.C., 2010. New trends in species distribution modelling. Ecography 33: 985-989. DOI: 10.1111/j.1600-0587.2010.06953.x

\section{Supporting Information}

The online version of the article includes Supporting Information:

Supp. Info. 1. Species distribution model
Supp. Info. 2. Fine-scale ecological niche analysis

\subsection{Phytosociological table}

2.2 Numerical classification and characterization of the regional woodland types

2.3 Regional woodland types, tree species compositions and ecological site classification (ESC) by plant indicator species

2.4 Correlation of tree to woodland types and correlation of tree species to substrate type and water soil regime

2.5 Ordination (DCA)

Supp. Info. 3. Tree ring analysis 